\title{
DOUBTS ABOUT DARWINISM
}

\author{
BY \\ A SEMI-DARWINIAN.
}




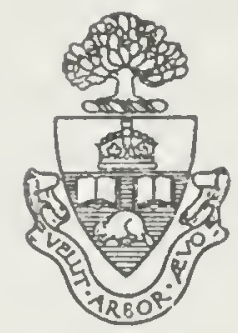

\section{Library}

of the

University of Toronto

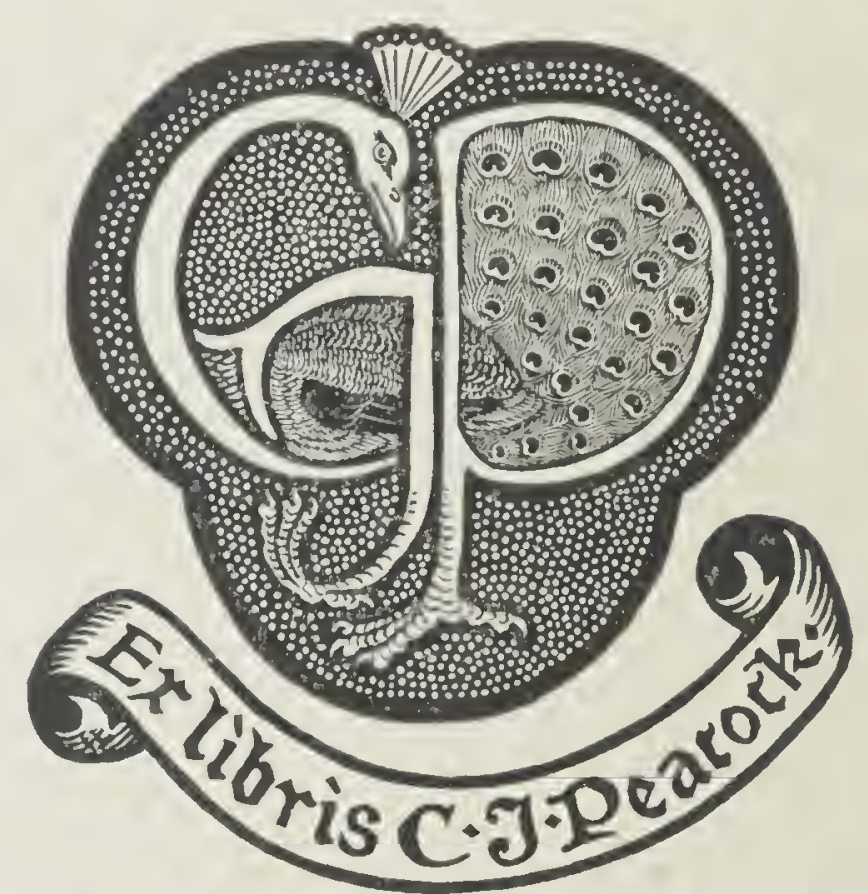

who folds a leafe downeye diuel toaffe browne whomakes marke or blotte yediupl roates hot whoffealeth thise boke ye diuelimall cookes 

Digitized by the Internet Archive in 2020 with funding from University of Toronto 


\section{DOUBTS ABOUT DARININISM}


With the Author's Compliments. 


\section{DOUBTS ABOUT DARWINISW}

BY

A SEMI-DARWINIAN

LONGMANS, GREEN, AND CO.

39 PATERNOSTER ROW, LONDON

NEW YORK AND BOMBAY

1903 
PRINTED BY
BOARD AND LONDON AND DORKING. 


\section{PREFACE.}

Is Lord Kelvin's Address to the British Association at Edinburgh in 1871 the following passage occurs :-

"If a probable solution, consistent. with the ordinary course of nature, can be found, we must not invoke an abnormal act of Creative Power."

The author has endeavoured to conform strictly to this principle. Darwin's theory of natural selection has been accepted in every case as far as it appeared adequate to accounting fairly for the phenomena; an additional cause has only been proposed where that theory appeared inadequate or inapplicable. 



\section{CONTENTS.}

CHAPTER I.

General

CHAPTER II.

Spontaneous Generation

CHAPTER III.

On the Dawn of Consciousness

CHAPTER IV.

Peopling of the Earth by an Aerolite

29

CHAPTER V.

On the Mystery of Reproduction

CHAPTER VI.

On the Care for Offspring 40

CHAPTER VII.

On the Formation of New Organs and Structures

CHAPTER VIII.

On Instinct . 
CHAPIER IX.

PAGE

Huxley's Suggestion of the Formation of New Organs by Larger Adrances

CHAPTER $\mathrm{X}$.

On Electric Fishes

CHAP'TER XI.

'Two Argmments of Darwin against the Theistic Argument from Design

CHAPTER XII.

Wallace's Limitations to the Law of Natural Selection $10: 3$

CHAPTER XIII.

Conclusion 108 


\section{PART I.}

\section{CHAPTER I.}

\section{General.}

'T'He title of this little book has been chosen to indicate that the author has no intention of attacking the Darwinian theory as a whole. He does not question the general doctrine of evolution on which it is based, nor does he desire to disturb the position of the 'Origin of Species' as an epoch-making book which has thrown a powerful light on the whole past history of animal life, and has given to the current of scientific thought a strong and permanent direction. He does not doubt that natural selection, or, to use Mr. Spencer's tarm, the survival of the fittest, has been a powerful factor in the development of the animal creation. He only follows Huxley, Darwin's great friend and support, in doubting whether this principle is adequate to account for the whole series of changes between the few low and simple creatures which Darwin postulated and the immense variety and complicated structures of animals with which the earth is at present peopled. It appear's from the 'Life and Letter's' of Huxley (vol. i, p. 176) that in his 
first letter' acknowledging' the receipt of the 'Origin of Species' he suggested that Darwin should not depend so entirely on his doctrine of the accumulation of small accidental changes for the production of improved animals. He writes, "You have loaded yourself with an umnecessary difficulty in adopting' the 'Natura non facit saltum' so unreservedly." And in a letter to Mr. Bateson only a year before his death he writes, "I see you are inclined to adrocate the possibility of considerable 'saltus' on the part of Dame Nature in her' variations. I always took the same view, much to Mr. Dar'win's disgust, and we used often to debate it" (rol. ii, p. 372). Huxley, in fact, supplemented Darwin by suggesting sudden jumps in the progress of improvement, which he compared to what gardeners called sports, and we may infer that he did not satisfy himself with Darwin's small accidental variations as an adequate cause of new species. His final judgment on Darwin's theory was expressed in his speech at the Anniversary Dinner of the Royal Society in 189. in the following words:- "The views which were propounded by Mr. Darwin thirty-four years ago may be understood hereafter as constituting an epoch in the intellectual history of the human race. They will modify the whole system of our thought and opinion, our most intimate convictions. But I do not know, and I do not think anybody knows, whether the particular riews which he held will be hereafter fortified by the experience of the ages that come after us." Te may infer from these words, in 
which, after ascribing to Darwin's work the rery high merit of having permanently changed the current of human thought, he expressly guarded himself against the application of this rery high eulogium to Darwin's doctrine of natural selection. He agreed with Darrwin on the general question of evolution; he agreed with Darwin and Spencer on the surviral of the fittest as the means of pruning away the least improved individuals of a species; but he did not agree with Darwin as to the adequacy of the cause assigned by him for the beneficial variations on which the survival of the fittest operates. He may therefore be fairly described as a semi-Darwinian.

There is nothing new in the doubt whether natural selection is the sole cause of erolution. Darwin himself admitted the co-operation of other minor causes. Later writer's have gone further in the same direction. But I do not know of any writer, except $\mathbf{M r}$. Wallace, who, while accepting evolution, and also recognising natural selection as the cause of a great part of the developments which have occurred, has maintained that another part can only be accounted for by supposing the intervention of intelligence and intention. Now this is the position taken up in the following pages; but as the respective parts attributed in them to the tro causes differ greatly from Wallace's division, the author has thought that there is room for further discussion of the subject.

Darwin never undertook to account for the origin of the fer creatures of very low and simple organi- 
sation which he postulated. Not only did he never publish any theor'y on the subjects, but, so far as can be inferred from his 'Life and Letter's,' he never expressed any private opinion. What was the reason for this silence: It is impossible that the question should not have presented itself to his mind. Was it that he had no opinion about it: Or that he did not care to expose himself to a second series of controversies? Or that he felt that the method of inrestigation which had succeeded so well with him so far-the collection of facts and experiments and inductive reasoning upon these-rould not be applicable to an event which must have occurred when there was no man to observe and record it? But it was inevitable that some of his disciples would not he content to remain at the point where he had stopped-that they would molertake to complete his theory by finding a mechanical explanation of the origin of these fer simple creatures, and so elininate the ideas of intelligence and design from this first stage of erolution, as Darwin had eliminated them, to his and their satisfaction, from all the later stages. They would regard Darwinism as a hody wanting a head, and would seek to find a head and fit it on. It was perhaps natural that after dispensing with a creator in explaining the immense variety of transmutations by which the higher vertebrates or man himself have been erolved from a little lump of protoplasm, they should think it hardly worth while to bring him back to make an amoba or a moneron.

Darwin is, of course, not responsible for this 
addition of the spontaneous generation of his primeval creatures to his theory of their subsequent development. Still, as the addition has been made, it is right to examine the argument in support of the former before we consider the latter. The first part of this book will therefore be occrpied with the doctrine of Spontaneous Generation. The second part will state some doubts as to the adequacy of natural selection to account for certain essential features of evolution, viz., the production of organs and structures, the faculty of reproduction, the origin of maternal and paternal instincts, and the deeper subject of the origin of consciousness.

Darwin did not undertake to discuss these three last subjects. To do so ras not necessary for the immediate object of his book. But if Darwinism is to take its place in science as a complete account of the origin and development of animal life, it must account for these phenomena as well as for others.

The doubts expressed in this book are confined to Darwinian principles in their application to animal life. Plant life is not discussed. The origin and development of animals must be of far deeper interest to human beings than the same subjects in the case of plants, on account of the inclusion of man among the former. Also a part of these doubts is founded on the maternal and paternal instincts and on consciousness, and has, therefore, no application to plants. 


\section{CHAP'TER II.}

SuONTANEOUS GENeRATION.

BEFon: the application of accurate scientific methods to the study of phenomena, spontaneous generation was the usual explanation of the appearance of creatures whose parentage was not obrious. But when facts began to be more closely examined, and the adequacy of alleged causes to produce the effects attributed to them came to be called in question, one case of spontaneous generation after another came to be disbelieved, and at last, in our own time, as a consequence of the controversies between Pasteur and Bastian, and the strict investigations to which they gave rise, it became the general conclusion of men of science that spontaneous generation is not a cause of organised life in the world with which we are acquainted - and that we ought to return to the old doctrine of Har'vey, Omue rieum ex oro. 'Therefore a return to spontaneous generation as a cause of organic life is a return to a doctrine which has been already held and then abandoned. Of course the answer to this objection will be that this cause of life was only active, and only occurred a very long time ago, in 
an earlier stage of the earth's progress, and that Darwin's primeral creatures may have come into existence then in a way which would not be possible now. Te cannot say positively that this may not have been the case; but when we come to examine Professor Haeckel's account of spontaneons generation we shall not find any reason for supposing that the condition of the earth was then as fundamentally different as this hypothesis would require. So far as the writer has found in English author's any suggestion on the subject, it has been that there may have been a combination of heat and moisture, and that this may have faroured the production of protoplasm. But the tropical regions fumish abundant localities in which heat and moisture are combined. Yet we do not find any production of protoplasm resulting. They farour the derelopment of seed or egos into plants or animals, but the seeds or germs must be there. We may therefore doubt whether this guess-for it is only a guess, not being based on any evidence-is a vere causu.

When a fresh-laid eg' is put into a hatching machine, at the end of a certain number of days a live chicken comes out of it. A savage wonld certainly conclude that the machine had produced the chicken, and that the-maker of the machine was a great magician. But we know that the machine has not the smallest formative power. It was a cock and hen who implanted in the egro the formative power which has formed the materials in the egg into a living animal. All that the machine has 
contributed is the temperature most farourable to the process.

Dr. Haeckel, who has always been a strenuous supporter of Darwinism, and goes further than Darwin, peremptorily rejects the idea of God, and substitutes for him spontaneous generation. From his zeal for Darwinism, and his eminence as a man of science, he may be considered a very competent champion of the cause. He will therefore be here regarded as having defended the case in the most complete manner possible. In his latest work, 'The Ridllle of the Universe,' published in 1899, he thus describes the origin of Darwin's primeval creatures by spontaneous generation. His immediate object is to explain the probable course of things in the other parts of the miverse; but as his ideas are derived from what he believes to have been the past history of om earth, we may take his description as applicable to the latter:-

"We are justified in supposing that thousands of these planets are in a similar stage of development to that of our earth, - that is, they have arrived at a period when the temperature of the surface lies between the freezing and boiling point of water, and so permits the existence of water in its liquid condition. That makes it possible that carbon has entered into the same complex combinations on those planets as it has done on our earth, and that from its nitrogenous compounds protoplasm has been evolved - that wonderful substance which alone, as far as our knowledge goes, is the possessor of organic life. 'The monera (for instance, chromacea 
and bacteria), which consist only of this primitive protoplasm, and which arise by spontaneous generation from these inorganic nitro-carbonates, may thus have entered upon the same course of evolution on many other planets as on our own; first of all, living cells of the simplest character would be formed from their heterogeneous protoplasmic body by the separation of an inner nucleus from the outer cell-body."

In his earlier work, 'The History of Creation,' published in 1876, Dr. Haeckel mentions the formation of protoplasm as a chemical compound of carbon, oxygen, nitrogen, and water, occasionally sulphur and phosphorus, as the first step. He employed the greater part of the first volume in a discussion of the subject, and in his later" work, "The Riddle of the Universe,' he not only insists on the same doctrine, but has extencled it to all the bodies of the miverse as a law which comes into action whenever the body has attained the conditions as to temperature, and in all other respects which farour it. These two works may be taken to state the case in farour of primeval spontaneous generation. The argument may be summarised as follows:-

He begins with the very remote period when the earth was a ball of liquid fire enveloped by heated gases, and shows how its surface gradually cooled into solidity, while the watery part of the heated gases fell in cooling to the earth as water. Ne may here observe that this view lispenses us from looking back further than the ball of liquid fire for mater'ial causes of the origin of life; for no such canses of 
life, or life itself, if they had existed, could have survived such a state of thing's. Then the surface became cool enough, protoplasm was produced by a combination of carbon, nitrogen, hydrogen, and oxygen. Sulphur and phosphorus are not mentioned as essential. It is the facility with which carbon enter's into combination with the other elements which makes life possible, so far as we know. It mar be here remarked that Haeckel does not mention the combination of heat and moisture as the canse of protoplasm. TVe must suppose that its production occurred at some period between the cooling of the gases into water-that is, below the temperature of $212^{\circ}$ - and the present state of thing's, in which there is no longer spontaneons generation. When Haeckel wrote the 'History of Creation' he believed that a rery remarkable discovery had recently been made, which enabled him to say that protoplasm was still being produced. Huxley had fished up from the deep sea a mass of something which he believed to be protoplasm, and to which he had given the name Butlyglin.: Haxlielii, in honour of its having appeared so opportunely. But on further investigation Bathybius did not bear out the hopes that had been entertained; and Huxley himself appear's to have given it up altogether. So far as appear's, it is doubtful whether it is a mineral substance in a gelatinous state, or, if it is protoplasm at all, it is protoplasm produced from the decay of some low organisms. At any rate, it camnot be counted on as evidence of the present production of protoplasm. The adrocates of spontaneous genera- 
tion must therefore fall back on the hypothesis that formerly causes were at work which were capable of producing it, but have now ceased to exist. Dr. Haeckel does not mention the combination of heat and moisture; we may therefore presume that he did not see in this an adequate cause. The condition of the earth from which Dr. Haeckel starts can have left nothing surviving it, except the materials of the earth and its atmosphere as we know them, and which do not produce protoplasm. Therefore the assertion of spontaneous generation, not being supported by experience or observation, or by definite reasoning on the operation of known causes, must be considered a mere hypothesis.

Dr. Haeckel expresses a strong hope that the progress of chemistry will aid in solving this difficulty. He states that in German laboratories great progress has been made in producing substances which have hitherto been considered as only producible by organisms, - that is, by living things. He writes:-

" Not fifty years ago all chemists maintained that we were unable to produce artificially in our laboratories any complicated combination of carbon, or socalled 'organic combination.' The mystic 'vital force' alone was supposed to be able to produce these combinations. When, therefore, in 1828, Wöhler, in Göttingen, for the first time refuted this dogma, and exhibited pure 'organic' urea obtained in an artificial manner from a purely inorganic body (cyanate of ammonium), it caused the greatest surprise and astonishment." He adds that since then "we have 
succeeded in producing in our laboratories a great variety of similar 'organic' combinations of carbon, by purely artificial means-for example, alcohol, acetic acid, formic acid. Indeed, many exceedingly complicated combinations of carbon are now artificially produced, so that there is every likelihood sooner or later of our producing artificially the most complicated, and at the same time the most important of all, namely, the albuminous combinations, or plasma-bodies."

Now, in judging of this subject we must distinguish carefully between two classes of substances which are found in a living body or proceeding from it. The first are those which form part of its organisation, which perform a function in it, which play a part in, and share in its life. The second class consists of substances which may have formerly formed an active part of its organisation, but which, having done their work, are now effete-are, in fact, dead. They are mainly the product of the waste of the tissues which is continually going on as long as life lasts. Now to which class do mea, alcohol, acetic acid belong:- Can a living body be made of urea and alcohol, formic acid, and any other product of German laboratories:

Let us suppose that the hero of Mrs. S'helley's norel of Frankenstein had really found out the art of making a man as she supposes, could he have made him out of the second class of substances: Would he not have said, I must have fresh protoplasm, unused protoplasm, living protoplasm, all this used-up refuse is of no use? 
In the above I have not raiser the question whether protoplasm has a structure, but if, as appears to be the case, it has a reticular structure, the difficulty of producing it in a laboratory must be greatly increased.

Dr. Haeckel proceeds to state that of still greater, nay, of the very greatest, importance to the theory of spontaneous generation are the exceedingly remarkable monera, those creatures which he has so frequently mentioned, and which are not only the simplest of all observed organisms, but even of all imaginable organisms. Seven genera had already been discovered when he wrote. Each consisted of a little lump of an albuminous combination of carbon. In some of these, by condensation of the substance at one point is formed a kernel or nucleus; in some the outer surface is hardened into a covering. They absorb particles of food which adhere to their surface. They more themselves formards by shapeless finger-like processes or very fine radiating threads out of their sul)stance. When they have attained the full size, they propagate themselves by division. A cell is an improved moneron, and all less simple bodies are composed of cells.

The cell theory greatly increases the difficulty of spontaneous generation. As now held by scientific men, it teaches that a cell can only be produced from a previously existing cell. Virchow's wellknown maxim-Omnis collula "colluli-expresses their conclusion. This is a positive denial of the production of cells spontaneously. It may of course 
be said, this is true of the present state of things, but formerly things were quite clifferent. But it must either be shown that there were causes known to us, which have since ceased to act, which would produce the first cell, or that there is good reason for supposing that there may have been such causes.

Dr. Haeckel goes on to say :-

"The oligin of the first Monera by spontaneous generation appears to us a simple, a necessary erent in the process of the derelopment of the earth." He adds candidly that "this process, so long" as it is not directly observed or repeated by cxperiment, remains a pure hypothesis. But I must again repeat, the hypothesis is indispensable for the consistent completion of the non-miraculous history of creation, that it has absolutely nothing forced or miraculous about it, and that certainly it can never be positively refuted." Again he writes, "If we do not accept the hypothesis of spontaneous generation, then at this one point of the history of development we must have recourse to the miracle of a supernatural creation. The Creator must have created the first organism, or a few first organisms, from which all others are derived, and as such he must have created the first monera, or primeral cytork, and given them the capability of dereloping further in a mechanical way. I leave it to each one of my readers to choose between this idlea and the hypothesis of spontaneous generation."

All this reads rather like an apology for the imperfect proof of the truth of spontaneous generation, and the inability to explain what were the causes 
which set the process in activity, and shows that the strength of the argument in his mind is rather' his arersion to the idea of what he calls a miracle.

Dr. Haeckel proceeds to state:-

"To me the idea that the Creator should have in this one point arbitrarily interfered with the regular process of development of matter, which in all other cases proceeds entirely withont his interposition, seems to me just as unsatisfactory to a believing mind as to a scientific intellect." If Darwin's theory is correct, that his few simple creatures contained in themselves the whole future of the animal creation, then the action of natural selection, their creation by a creator can hardly be called an exception to his usual mode of proceeding. It was the setting in motion a cause which, acting through the ordinary laws of matter, was to produce an immensely long series of development. Besides, if it shall appear that natural selection, though it will account for a great deal, will not account for ererything, but requires to be supplemented by the interrention of a creator, the creation of a moneron will not be the sole action to be ascribed to him; and his principle will appear to have been to leave the established laws of nature to act without interference, except in a case where they are inadequate to produce a desirable result, and then to interfere so far as may be necessary to supplement them; the interrention of a creator in the first production of a living being will appear to have been only the first of a series of interventions.

Dr. Haeckel writes that the origin of the monera 
appears to be a simple necessary event in the process of the derelopment of the earth amid all the other morements that were going on in the framework of the earth and the chemical combinations and dissolutions which the other combinations of carbon were undergoing. In this statement he entirely ignores the immense difference between the results obtained. These other combinations of carbon doubtless may have produced reactions and actions on other inorganic substances rery interesting to the chemist, but that is all. But the one combination has fumished the material out of which protoplasm has been formed or has formed itself, and is the physical basis of all life, and is that which, by being formed or forming itself into a cell, has started the immensely long evolution of animals, including man himself. It must therefore have contained some power, some virtue, whether we understand it or not, capable of producing all these results; while any of the other compounds of carbon, if put in its place, would have remained inactive for ever, so far as the production of life and organisation is concerned.

Let us consider the various stages which this compound of carbon has to pass through according to the doctrine of spontaneous generation adopted by Dr. Haeckel. First, all the chemical elements which contribute to form protoplasm had to come together in the proper proportion; then these had to form the requisite chemical combinations; then they had to form themselves into the reticular textures characteristic of protoplasm; then a part of 
the substance had to form itself into a cell with a nucleus. 'This seems a fairly complicated piece of work to be accomplished by a collection of atoms without any assistance from intelligence; for spontaneous generation excludes all idea that any intelligence was guiding the atoms in their work; and as for the atoms, I lo not think that any one has ever suggested that they had any intelligence until they were at least formed into a monad.

Then, as to the opinion that the spontaneous formation of a monad was a necessary event. It was a necessary event for Dr. Haeckel's theory, for how could he have carried on his argument unless he had at least a live moneron to start from; but as to any necessity in the nature of things, this is not apparent. The world of inorganic matter would have gone on as well, and carbon might have carried on its combinations, including that particular combination which produced protoplasm, without the results of opening a new world - the world of life and intelligence-the connection of which with the first world of matter and physical forces is so incomprehensible to us. 


\section{CHAPTER III.}

\section{On the Dawn of Consciolsanes.}

Ir spontaneous generation is to be accepted as a sufficient cause of the production of living animals on the earth, it is necessary that it should not stop at bringing together the chemical elements which are common to all animals, and arranging them into the structures which are required for the performance of the morements and functions of life. Animals finished up to this point would be like Descartes's idea of the lower animals, automatons moring about and performing all the necessary functions of life, but insensible, unconscious, incapable of intentional action. The one thing wanting would be consciousness. The word is here used to comprehend all psychical states, whether sensations, feelings, pains, pleasures, or thoughts, ideas and volitions-every state which distinguishes a living animal from a regetable. This explanation is given because it is sometimes used in a more restricted sense. Tre may assume that in the rery first creatures which appeared this consciousness would be present in a rery imperfect condition, as in the amoba, which seems to show it only by protruding 
a part of its substance to seize a nutritions particle when it is hungry. But the faculty must have been there, and capable of the immense development which it was to acquire in the descendants of those animals; otherwise evolution fails to account for the consciousness of the higher animals and man, and another cause must be found for this. Its faint dawn in these primeval creatures was to grow into the brighter state of feeling and intelligence in the superior animals, and in man, until it reached its highest degree in the full blaze of genius in a Newton or a Milton.

How, then, were the first animals endowed with this faculty through spontaneous generation: The ancient Greeks tell us that when Prometheus had made a man, there was something still wanting. It was the sacred spark which gives life and consciousness to the natural body. He climbed to hearen and stole fire from .Jore's altar. But in Dr. Haeckel's system there is no heaven, no altar, and no Gorl. We must therefore seek elsewhere for this sacred spark. In order to appreciate the greatness of the work, let us see what had to be accomplished. First, what was to be the seat of this faculty of consciousness: Or, to put the case in another form, what was to be the organ of which consciousness was to be the function: There are two theories, and only two, on this subject. One is that every man has not only a material body, but an immaterial soul, and that all psychical actions in his consciousness take place in his soul, as all movements in space take place in his body. But we need not consider 
this opinion at present, as it is certain that the believer in spontaneous generation will not adopt it, for it would throw upon that principle the production of an immaterial soul, a thing utterly foreign to his system. The other theory denies the soul, and asserts that all psichical phenomena are generated in the body, or, more precisely, in the brain. As the lowest animals have no brain, it is supposed that those with whom creation began were endowed with a rudimentary conscionsness diffused through the body, which was afterwards concentrated in a brain, as is supposed to be the case with the lowest animals at present. Let us now consider the composition of this brain. It consists of an immense number of atoms, of which the most important are the ingredients of protoplasm, viz.:-carbon, oxygen, hydrogen, nitrogen, with or without phosphorus and sulphur. The exact number has not been ascertained. But all estimates agree in this, that there are at least such an immense number of millions in the whole body that if we assume that there are one million of atoms in the brain alone we shall be rery far below the reality. Let us therefore take this figure, so that we may have a definite figure before us, and be sure not to exagorerate.

The reader is requested to remember whenerer he finds this number used, that it represents a far larger, though unknown, number. 'The brain is thus composed of a million of atoms, and all these atoms are to he derived from the innumerable atoms of the same elements which are at large in the world, and which are entirely destitute of conscious- 
ness. At least no one has asserted that they have any trace of this faculty. This million of atoms have been brought together, arranged into the structures which anatomists find in the brain, and now all the variations of feeling, perception, thought, and rolition at once show themselves. That is the canse of this appearance of mental states of which there was nothing before: We shall be told that the particular arrangement of the atoms has produced certain actions of the atoms, and that these are the causes of these thoughts or feelings. Now all these actions of the atoms may be resolved into movements, or forces tending to movements, and one can understand that these should cause other movements of the same kind; but how can they cause thoughts and feelings, thing's which belong to another world than that world of space in which motions of material substances take place? For let it be observed that thought and feeling to not occupy space, or move in space, as atoms do. If this proposition appear's paradoxical, let the reader try to speak of a thought and feeling in terms of portions of space-to say, for instance, "I have a pain seren inches long," - and he will see the incongruity of the conception of thought or feeling as occupying space. Natural philosopher's have admitted that there is no visible or conceivable connection between the two classes of facts. A passage in 'Tyndall's address to the Phrsical Section of the British Association at Norwich in 1868 may be quoted as an example of this opinion :- " Granted that a definite thought and a definite molecular 
action in the brain occur simultaneously; we do not possess the intellectual organ, nor apparently any rudiment of the organ, which would enable us to pass, by a process of reasoning, from the one to the other." The natural inference appears to be that there is some invisible power which causes the atoms and their movements to exert the power of producing thoughts and feclings which they do not naturally possess; and that without the intervention of this power the connection between the two classes would never have arisen.

Professor Drummond ('Ascent of Man,' page 158) quotes Huxley as follows:- "I know nothing, and never hope to know anything, of the steps by which the passage from molecular movement to states of conscionsness is effected," and Clifford as writing, "The two things are on two utterly different platforms; the physical facts go along by themselves, and the mental facts go along by themselves."

Again, he quotes Du Bois Reymond as writing, "It is utterly inconceivable that a number of atoms of carbon, hydrogen, nitrogen, oxygen, and so on, shall be other than indifferent as to how they are disposed, and how they move. . . . . It is utterly inconceivable how consciousness shall arise from their joint action ('Ueber die Grenzen des Naturerkennens')."

Locke, in his second letter to the Bishop of Winchester, when he wished to show that materialism is not necessarily incompatible with Christianity, suggested that we might believe that God, being 
ommipotent, might endow matter with the faculty of feeling and thinking-here called consciousness. He thought this possible to One to Whom ererything is possible-but to no lesser cause.

But where is there such a cause in the doctrine of spontaneous generation?

Let us turn to another point. It is certain that a man's brain is composed of a number of atoms, which are inadequately represented by the numbera million. But it is also certain that he feels as an unit, thinks as an unit, wills and determines as an unit-that he is quite unconscious that he is anything else. The only way in which I can explain it is to consider that the million of units are made one unit by some adequate power for the purpose of consciousness, though remaining distinct atoms. Here, again, we camnot explain how this result was accomplished, and can only infer some adequate cause. But we may claim that the advocate of spontaneous generation should either explain how his principle will account for it, or acknowledge that it is inadequate, and that the effect produced must be the work of some higher power. Let it be remembered that the case is entirely distinct from that of a number of men who are said to be unanimous or of one mind on any question. All that is then meant is that every individual mind thinks independently on the question, but that all the minds thinking in the same way have arrived at the same conclusions. But when a man's million of atoms are said to be one person, and are said to think in a certain way, this does not mean that each 
atom, thinking by itself, arrives at the same conclusion as all the other atoms, but that the ag'regate number think as one person in the way specified, while they as individuals do not think at all, and indeed cannot think.

Not only is one mnit of consciousness made by conversion of millions of atoms into one unit so far as consciousness is concelned, but it is not necessary that ther should be the same mits. When Darwin wound up the argument of his 'Origin of Species' by his recapitulation and conclusion, the brain which directed his pen was not the same as the brain which dictated the first chapter. For between the two a long interval of time had intervened, during which the used-up particles were being removed from the brain in accordance with the usual comrse of vital changes, and replaced by new particles. 'This process was accelerated by the hard thinking which accompanied the composition of the book, if the general law which causes increased rapidity of change to accompany increased work of the part extends to the action of the brain, so that a consiclerable part of the atoms which composed the chapter of conclusions had no part in the commencement of the work; and yet there was nothing to indicate either to the anthor or his reader's that the former had been partially changed during the process.

There have been authors who have spent trenty years in the composition of one book. I suppose that during that long period all the atoms of their brains may have been changed for new ones. In snch a case 
the statement of the writer's opinion and object in the first chapter would have been made by one set of atoms, while the conclusion in the last would have been dictated by another set, who had had nothing to do with the statement in the first, and not much to do with the arguments by which it was supported in the intervening chapters. A theist would ascribe this phenomenon also to God. To what will the belierers in spontaneous generation ascribe it:

I believe the usual way in which this difficulty of the permanent mity of the mind, although the atoms which compose the brain are continually changing, is surmounted, is as follows:-All thought and feeling are caused or accompanied by certain morements of the particles of the brain, whether these morements take the form of impressions stamped on the brain, or currents through the brain, or any other form. These morements leave their traces on the structures of the brain, and these traces direct its future action, varying the morements of the atoms passing through them, whether these are old atoms or new-and the man's thoughts and feeling's being caused according to the motions of the atoms, whether these are old or new. Thus, for instance, the thoughts of Darwin while writing the first chapter's of the 'Origin' had left traces in the structures of his brain ; these traces cansed corresponding movement in the atoms which were present at the composition of the last chapter. Let us accept this explanation. Then how wonderful must be the structure of the brain which can carry all these traces of old thoughts through life; and how wonderful must be the arrangement by which the 
new thoughts are produced by the passage of new movements orer these traces; and how wonderful must be the cause which has produced the effect.

I have endeavoured to state fairly the doctrine of the second theory on the subject of the organ of consciousness. But I confess I have nerer been able to conceive that it is not one thing which thinks, feels, and wills, but a million of things. It does seem to me that, whatever I am, at least I (that is, my sentient, intelligent self) am one thing and not a million of thing's. I have felt, with Locke, that in order to believe this I must fall back upon the theory that it must be the work of Omnipotence. I have therefore tried to find out why other's do not appear to feel the same difficulty. It has occurred to me that one cause may be the imperfection of our senses, which causes us to see the body of a man or other living being as if it was some continuous substance, and therefore an unit. It is hardly necessary to say that this is a pure illusion. A man's body is an assemblage of millions of atoms, or rather of millions of millions of atoms: temporarily brought together. If a pair of spectacles could be found which magnified so enormously that with them we could see the individual atom, we should at once perceive this. These atoms are not even in contact with one another. All chemists are agreed that between the atoms of a body there must be empty spaces. I do not know whether any opinion excepts the atoms which are combined into molecules; but if this is the case, the intervals between the molecules must be the larger. 
Even without special knowledge of chemistry, I think our own mind would incline us to think that the atoms of our body are not packed close together like the little cubes in a mosaic table. The theory of Boscovich will carry us a step further. He thought that the most solid bodies are composed of minute points, the intervals between which are many times larger than the points themselves. I am not aware that his doctrine has ever been refuted, after haring been announced to the scientific world about a hundred and forty years ago, and believe it has been generally acquiesced in. If the reader will take a piece of white paper, scatter upon it a number of grains of sand or flour very thinly, take care to make the intervals between every two grains far larger than the grains, he will then have some idea of what his brain is according to Boscorich; and perhaps he may then understand my difficulty in conceiving how a million of points so scattered can have one thought, one feeling, one pain.

There is a way of avoiding the difficulties of the theory of the brain as the organ of consciousness; this is to fall back on the other theory of an immaterial soul. If this is not proposed here it is because that theory has also difficulties of its own which I do not pretend to be able to remove.

But as the object of this chapter is to indicate the difficulties which the question of the origin of conscionsness opposes to the doctrine of spontaneons generation, it is unnecessary to consider that other theory, since, as has alreadly been remarked, it demands the production of an immaterial soul, which 
the believer in spontaneous generation will certainly reject. He may, of course, deny Tyndall's assertion that there is any mystery about the connection between psychical and physical phenomena, and say that it is as natural that a molecular motion in the brain should produce a pain, or a thought, or an affection, as that the striking of a piece of steel on a flint should produce a flash of light, or that an electrical current should separate a compound substance into its elements. But unless he is prepared to do this he must admit that there must be a cause which illuminated the brains of the creatures which, for the sake of argument, we have supposed that spontaneous generation has put together for him. 


\section{CHAPTER IV.}

Peopling of the Earth by an Aerolite.

IF the theory of spontaneous generation is rejected, is there any other theory which purports to account for the first appearance of the primeval creatures postulated by Darwin without the intervention of a creator? I only know of one. It has been suggested that on the break-up of some stellar solar system, attached to which was a planet possessing an animal and vegetable system like our present system, some seeds of plants and ova of animals happened to adhere to a fragment of matter, which started on its travels through the rast interstellar spaces; having in the fulness of time reached our earth, and having fortunately landed on a piece of dry ground, the soil of which was suited to the seeds and ova, began to people the earth. This hypothesis assumes the occurrence of some catastrophe such as would be caused if our solar system came into collision with another sun, and we shall be better able to judge of the theory if we suppose that our system is the one to be broken up, and that a fragment from our earth is to start on its journey towards the planet which it is to people. To make the journey as short as possible, let us suppose this 
planet to be attached to Alpha Centauri, which is only some millions of millions of miles distant from us. The only force which we know of which can break up a system like ours is a collision with another great sum. Now the first difficulty of the theory is the intense heat which would be generated by the encounter, a heat sufficient to reduce seeds and ora into cinders, or rather to dissipate them into gases. The next is that, in order to start on its colonising mission, the fragment of rock or earth would have to be impelled with a velocity great enough to orercome the attraction of the mass of our solar system, which would not be diminished in weight by the collision, and great enough to carry the fragment to a distance at which the attraction of some other stars would determine its future conrse. A third is that we do not know whether Alpha Centauri possesses a planet so closely resembling our earth in temperature, quality of atmosphere, soil, and water-supply as to suit the earth's production. But a final difficulty is that if all these difficulties could be orercome, the problem would only be remored one step backwards; for we should have to inquire how the planet acquired its population of plants and animals, and this would raise the same questions as in the case of our earth. 


\section{PART II.}

\section{PRELTMINARY.}

Thus far we have only been concerned with Haeckel's theory of the origin of living being's by spontaneous generation. We have now to consider Darwin's theory of their development by natural selection.

In Darwin's 'Descent of Man' (vol. ii, ch. xxi, p. 395), the following passage occur's:-

"I am aware that the conclusions arrived at in this work will be denounced by some as highly ir'eligious; but he who thus denounces them is bound to show why it is more irreligious to explain the origin of man as a distinct species by descent from some lower form through the laws of variation and natural selection, than to explain the birth of the individual through the laws of ordinary reproduction. The birth both of the species and of the individual are equally parts of that grand sequence of events which our minds refuse to accept as the result of blind chance. The understanding revolts at such a conclusion, whether or not we are able to believe that every slight variation of structure-the union of each pair in marriage-the dissemination of 
each seed-and other such erents, have all been ordained for some special purpose."

Here Darwin, by the use of the words "om" minds," appears to associate himself with those who refuse to accept blind chance as the cause of the grand sequence of erents-in other words, of the origin and evolution of man-to say that his mind revolts from such a conclusion. And the meaning of the whole passage appear's to be that, while rejecting' the belief that every minor erent has been ordained for a special purpose, he would not be opposed to an opinion that a higher intelligence presides orer the grand sequence as a whole. It may therefore be hoped that he would have received with indulgence, if not with approbation, the riew taken in this book, that while the ordinary course of events has been left to rm on withont interference, this higher intelligence has intervened at certain stages of progress; first to initiate the evolution by bestowing life on the primeval creatures for whose origin Darrin did not profess to accomnt, and afterwards by causing animal life to take a new departure where one was required.

This quotation is therefore prefixed to this second part, in which an attempt will be made to indicate the points at which such a new departure appeared to be required. 


\section{CHAPTER V.}

On the Misteriy of Reprodection.

'THE first living creatures which appeared on the earth must have been already provided with the means of producing creatures like themselves, for otherwise, at their death, all life would have ceased with them. Every generation of animal since the first must have inherited this faculty, for otherwise life would not have continued to our time. We are so very familiar with the fact that the power of producing their like is an universal property of all animals, that we are liable to take it for granted, as a matter of course, and to forget what a wonderful power it is.

If the first living things were like the amoeba, the prorision made for perpetuating their kind was their dividing themselves into two halves, each of which became at once an amœba. But the process became more complicated as the structure of the animals became more complicated, till in the higher Vertebrata, such as the Mammalia and birds, a considerable part of the body is devoted to reproduction, and furnished with a system of structures capable of producing the young animal. It is the formation of 
these structures and their mode of working of which we are to ask the explanation from the Darwinian theory.

Darwin did not deal with this question. To do so was not required for the immediate object for which the 'Origin of Species' was written. But the case is different when his book is proposed as giving a complete account of the origin and progress of animal life from its first appearance. TVe then have a right to ask of that theory how the power of reproduction was acquired by the earliest living creatures, and how it has been transmitted without failure to every generation of their descendants.

Our extreme familiarity with the fact makes it difficult for us to realise its importance and strangeness. To assist us in effecting this, let us take the case of a child, whose attention has not yet been directed to the subject of reproduction. Let us suppose him to come back from a risit to the Zoological Gardens, saying that he had seen a wonderful sight. He had been shown a pair of monkeys from Africa with a little monkey alongside of them, and the keeper had told him that the little monkey had come out of one of the monkeys, and that the latter had inside her a little machine for making monkeys just like herself, only smaller, which she turned out quite finished and all alive; that the little monkey, if well supplied with food, would grow as big as the mother, and, if a female, would begin to make little monkeys in her tun'n. Our first impulse would be to tell the child that there was nothing at all remarkable in all this; 
that when he grew up he would see that all female animals make little animals like themselves. But would not a little reflection show us that the child was right - that he had seen a wonderful thing, and one the explanation of which is, to say the least, exceedingly difficult?

Again, let us suppose that a manufacturer of clocks and steam engines were to tell us that he had constructed a little machine which, when fixed on a clock or a steam engine, would begin to make clocks or steam engines just like the original. We should, of course, not believe him, not only because we know that the only machines which, according to our experience, produces other machines like themselves are the living machines which are called animals, but because we should certainly find on examination of his machine that its machinery was not adequate to the work professed to be accomplished by it. Let us, then, examine in the same way the

\section{Mystery in a Hen's bit!l,}

in order to find an adequate cause for the effect which we know to be produced in it. We might choose as our example the production of a young mammal produced from an impregnated ovum, as it issues from its mother completely formed and alive. But in that case, as the whole process of development takes place inside the mother, it might be supposed that she had exercised a mysterious influence, though I believe scientists will tell us 
that she only supplies nutriment out of her blood to be worked up into the future mammal, and maintains the ormm in an equable temperature; in fact, she only supplies board and lodging to the embryo. Therefore let us take a fresh-laid eg'o and car'y it at once to a hatching machine; we are certain that the machine will not exert any formative influence upon it, but will only maintain it in the temperature which experience has shown to be most favourable to the de velopment of the contents of the ego. The know that the result will be that in about twenty days there will emerge from the shell a chicken completely formed and alive, which will at once begin to run about and pick up food. Let us now dissect this chicken. Tre shall find it composed of a great number of structures, and, on applying the microscope, we shall find these composed of tissues and details invisible to the naked eye, and the whole excellently packed up in the form of an animal. In order to appreciate the wonderful transformation which the contents of the eg' have molergone during the twenty days, let us open another ego: The shall find the yolk of the eg'g enveloped in a membrane, and a fluid mass which is the white of the egg, and we shall find nothing else. What is the formative power which has transformed these two substances, which had no perceptible structures at all, into the very large number of structures which are found in the chicken? The only answer which re can make to this question is to confess our absolute ignorance. But perhaps it may be said that this is too absolute a declaration-that it ignores 
all the discoreries which biologists have made by opening a great number of egges at all stages of development. It is true that biologists can tell us hour by hour all the progress made in the process of conversion of two structureless substances into a live chicken. But that throws no light on the question, what is the formative power which causes the whole process. One certain truth is that this cause is invisible, and therefore if the microscopist observer's were enabled to see through the shell of the egg, and were to watch everything which went on inside it from the moment when the $\mathrm{eg}^{\circ}$ was laid till the chicken came out of it, they would learn no more than we know at present.

Let us now turn from the mode of reproduction of oviparous animals, which we have studied in the hen's egg, to that of riviparous animals such as the Mammalia. In these the young animal is dereloped from the impregnated ormm, which for this purpose is retained in the body of the mother, and supplied with nutriment from her, which it converts into the substance of the embryo, working up, as it were, this material into all the tissues, structures, and organs which constitute the young animal. In one respect the process is still more remarkable than in that of the bird's egg, because the impregnated orum is microscopically minute compared with the size of the young animal, colt, foal, pig, or infant into which it forms its materials. As has been already mentioned, the body of the mother is not supposed to take any part in the manufacture beyond supplying 
the raw material. In this case the microscopically small ormm must possess a formative porrer so strong and well directed that it can produce ont of this material and itself an animal complete in all its parts. But what that formative power is we are utterly mable to say. As in the case of the oriparous species, scientists have ascertained by dissection all the stages through which the embryo passes till its exit from the womb complete and alive. But of the nature of the power which conducts it through all these stages they remain entirely ignorant, and the Darwinian must acknowlerlge the inability of his theory to solve the mystery.

'Thus far we have been concerned with the mystery of the production of a young animal ont of an old one as an universal fact which any theory has to accomt for. But there is another general fact to be accounted for, that the young one is intended to he a copy of the parents. If the reader is told that we know no reason why this should be the case, his first inclination will probably be to consider the assertion unreasonable or paradoxical. He will probably say, of course, a dog, if it produces anything, will produce a dog', a fowl a fowl, a human being a hmman being. That else should they produce? But if he will try to put his riew of the causes which fix this result into a distinct shape, he will find it more difficult than he thinks; at any rate, Darwin himself thought the difficulty great enough to require a separate theory to account for it, and propounder his theory of pangenesis for that purpose. It is true 
that he had in riew not the inheritance by the offspring of those greater features which decide whether two birds are to be ranked in the same species, but the smaller individual peculiarities which distinguish individuals from others of the same species. It is also true that pangenesis has not been adopted cordially as a part of Darwinism; and the subject is only mentioned here to show that Darwin considered the resemblance between parent and child a fact which requiress an explanation, and that it came within his functions to explain it. 


\section{CHAPTER VI.}

ON THE CARE FOR OFFSPING.

The provision for the perpetuation of life on the earth, discussed in the last chapter, wonld have been very imperfect if it had not been accompanied by the existence in female animals of the care for offspring, which causes them to take all requisite precautions for their safety and for their ohtaining food up to the time of their maturity; and if the males had not been also concerned in this good work in cases where their aid was necessary. The expression, "care for offspring," rather than maternal and paternal affection, is used in order to comprehend the case of those insects who, while they take great pains for the future welfare of their offspring up to the time of the deposit of the egos, go away immediately afterwards and never see what becomes of them.

The kind of care taken varies according to the kind of animal, being suited to the wants of the offspring in each case.

The only exception is in the case of the lowest class of anmals like the monera and the amoha, which perpetnate their species by division of themselves. The mother, if she can be so called, divides 
into two amoba, and therefore ceases to exist. The tro children, being complete amobas, have no need of further care.

On the contrary, the relation of all the higher vertebrata to their offspring may be shortly described by saying that it is exactly like that of human mothers towards their children. They nourish them with their milk, they provide them with food, they take care of them when they are suffering, they expose themselves to danger to sare them, the most timid become bold in their defence, they show all the signs of measiness and grief when things go wrong with them. There is only one difference, but this is an important one. The human mother's affection continues after her' children are grown up and are independent of her; and if circumstances should call for the renewed exercise of her tenderness and devotion, she will bestow these as freely as when they were young; and if they die she will mourn for them. The feeling of a quadruped mother, on the other hand, stops short at the point where it ceases to be necessary for the young animal's preservation. She forgets the former relation between them, and if one of them is killed or in danger she will look on withont any greater feeling than she would show in the case of a stranger. This difference strongly suggests that the feeling is not spontaneous, but has been implanter in her to secure her care for her young while they need it, and is allowed to die out when they cease to want it.

Birds, again, act from the moment of their mar'- 
riage with the male bird till the time when their yomng are able to fly and to provide for themselves, as if, accorting to the doctrine of metempsychosis, the soul of a human mother has entered their bodies. In one respect their care is superior to that of quadrupeds, for it begins before their children's birth. They set to work building a house in which the female may hie and nurse her children, and educate them till their maturity. As this is hard work, her feathered bridegroom is inspired to share her work. When the eggs are laid she derotes herself to the patient work of hatching them. As she is thus debarred from foraging for herself, and, after the egos are hatcherl, for her children, the male is again inspired to feed her and them besides himself. He bring them in his beak many a fat worm which he himself would like to swallow. This continues until the young hare g'rown their feathers and are able to fly. The nother then renders a last service to the young birds by enconraging them to fly, and then departs and forgots all about them.

Here, again, we have a mother providing diligently, and apparently intelligently, for her children before they are born, devoting herself to their hatching and subsequent wants, and ceasing her derotion as soon as ther can do without her. And we have the male bird inspired with a large share of devotion to the task of feeding the mother and her children, not displayed by other males, when the process of sitting on the egos and hatching them prerents her from procuring food for herself and for 
them. The devotion of father and mother lasts just as long as the young need it.

The case of insects is more complicated. Some exercise care for the young in a very high degree. The bees may be taken as the best known example. They begin by building a house in which they provide a separate cell for each future young bee, and a larger cell for the queen bee who is to produce them. They lay in a large supply of food beyond what they want for themselves, in order to secure the young from future want. But all this can hardly be brought under the category of care for offspring, for the young are not their children, but those of the queen bee, who does not pay the least attention to them, and, in fact, does nothing besides eating and producing egg's. The case of the bees must therefore be considered exceptional. Their community is a sort of Plato's Republic, where the rule is all for the State, nothing for the individual. Each inmate of the hive is confined to its particular work as if by a superior authority. The working females kill off the males as soon as they have done their part in impregnating the queen. She is shut up to work at producing eggs; and the workers derote themselves to do all the work of the community.

A more ordinary case is that of the insects, who, when they are about to shed their egg's, select a suitable place where the young who are to issue from them can go through their metamorphosis successfully. Many insects bore a hole, deposit the egg's in it, and then go away and never care about them afterwards. The most remarkable case is where the 
female, after lahouring to produce a chamber, and depositing the egos in it, puts in a supply of food for the romng insects, then goes away, and nerer comes back to see what has become of them.

From this summary it appears that in the case of the Mammalia maternal affection accounts for the behaviour of the mothers. But how is the origin of this affection to be accounted for: It has been suggester that the young animal, by sucking the mother's milk, at once relieres her from what would otherwise be a painful burthen and establishes an agreeable relation between them, and that this will account for the production of a kindly feeling in her. If this is considered a sufficient cause for the generation of so powerful an affection, let us consider it thus accomnted for. But in the case of the insect, and in a lesser degree in that of the bird, why is there such a curious mixture of care for the welfare of the young with so complete an apparent inclifference to their after fate? Why does the insect seek a place for the deposit of her eggs, always choosing a good site where the egg's may he expected to mature undisturberl and find food suited for them: Why do some insects go farther, and bore or excavate a hole or chamber where the egos will be more secure: Why do some insects take the additional precantion of depositing with the egos a provision of suitable food for the roung who will issue from the egg's Are we to suppose that the intelligence of the insect extends so far that it foresees that its pregnancy will be followed by an issue of eggs, that these eggs will 
give birth to creatmes like itself, and that these creatures will require to be fed in their nurseries until they are able to more about and forage for themselves: And are we to understand that the contemplated birth of these future children whom she will never see has stirred up in her a maternal affection, which induces her to undertake a great deal of labour to carry out all these operations: If the answer to all these questions is yes, how did all this knowledge and all this affection arise in the insect's consciousness? If the answer is no, how has she been caused to perform all these operations, which can do no possible good to herself? Why does she not let the eg's lie where they fall, like her excrement? We have not the opportunity of asking Darwin how these questions should be answered with respect to insects in general. But we have a specimen of what his opinion would be from that which he gave in a letter to Romanes on the case of the sphex, which will be quoted in a later part of this book. From this, and from his riews in general, we may infer that he would have said that the insects of the present day select the place for their egg's, make the hole for them, deposit them, and put with them food by instinct; that is, follow a routine of action the use of which they do not understand, but which their ancestors did understand, and practised until these actions became a habit, and as such were transmitted to all their descendants. A similar explanation would apply to the bird building a nest before she had any young to put in it, and sitting 
upon the egos before she had any reason to believe the young birds would in this way be hatched from them. Let us now suppose a female insect feeling that she had a burthen from which she was likely to be delivered. Trould not her first impression be that it was like her excrement, a thing to be got rid of, and after it had been shed that she was well rid of it? But let us go back to the first insect who bored a hole. Could she foresee that she would produce egoss which would change into insects like herself? If the answer be in the affirmative, she must have had a maternal feeling in farom of the umborn children whom she would never see; and another question arises, how did she acquire the faculty of feeling? If we answer in the negative, why does she impose on herself so much labour to accomplish a work from which she cannot expect any pleasme or adrantage?

All these considerations at least justify a doubt whether the Darwinian theory accounts for the begimning among insects and birds of the care for offspring, and whether they do not require the supposition of some intelligent power having intervened to implant in them maternal affection, or at least a care for offspring and a knowledge of what that offspring would reguire. 


\section{CHAPTER VIT.}

On the Formation of New Organs and Structures.

Waldace, in his 'Darwinism,' quotes a declaration of Darwin's that it is almost impossible to conceive how the first rudiments of important organs can have been of any use; or how, if they were not of any use, they can have been preserved to further development by natural selection. Now as one of the principal objects of this book is to present the reasons why natural selection cannot have been the cause of the evolution of new organs, and Darwin's words come so near to saying the same thing, it would seem that this chapter, which is to give these reasons, might begin and end with the above quotation. For it expresses in a few simple words a summary of the main argument. But as Darwin, in his 'Origin of Species,' does not draw a distinction between the evolution of new organs and other improvements, but describes natural selection as the cause of evolution in general, he must be regarded as putting forward this process as the canse of both. The argument must, therefore, be pursued independently of the remarkable admission quoted abore.

It will he understood that it is not intended to raise any doubt against the doctrine of natural 
selection as a powerful agent in the modification of animals and their adaptation to the external circumstances in which they are placed. It is only intended to express a doubt whether it can do everything, and especially whether it can generate a new organ or a new structure, or whether a new cause is not required for this purpose. In order to appreciate the immensity of the work which has to be accomplished, let us consider the point from which erolution must have started, and the result which has been ohtained in the production of one of the higher vertebrates. Let us set before our minds on one side a moneron or an amoba, and on the other, let us say, an anthropoid ape. Let us then imagine the ape to be dissected. We know what we shall find-a great number of organs and structures, filling the whole space enclosed by the skin, and erery one of which is adapted to perform some function; and, on the application of a powerful microscope, we shall find that each of these is made up of tissues and details invisible to the naked eye, the whole forming a machine which, in number and minutiae of parts and in the multiplication of functions to which it is adapted, excels very far the most complex product of human ingenuity in derising, and skill in executing, the most remarkable of machines of human construction. Of course, the monkey is something very much more than a machine. It possesses life, intelligence, will. But, for the present, we are regarding only its qualities as a machine. If we now turn to the amoba, and make an equally strict microscopic examination in 
order to discover some beginning of all these things, we shall find nothing at all-no organs, no structures, nothing but a piece of protoplasm thickened in one part into a nucleus. If now we attempt to divine how this beautifully constructed and excessively complicated body of the monkey can have been produced out of the small piece of structureless protoplasm, our first idea would, I think, be that it must have been the work of a very great intelligence having the power to carry out whatever it has willed. But here Darwin intervenes, and tells us that it has not required any intelligence at all. The whole work has been accomplished by an immensely long series of accidental variations. And when one of these variations happens to tend torards an improvement, the law of the survival of the fittest comes in by giring the individual possessing the small beneficial variation a slightly greater chance of survival and transmission of the variation to its offspring than the chance of its competitors, the other animals of the same kind. Each individual case will only carry this beneficial rariation a rery little way. But, the Darwinian will say, the number of generations between the amoba-like creature and the monkey has been so immense that there has been time for the accumulation of small beneficial variations to produce all the organs, all the structures, which characterise the monkey.

But will any number of variations produce the kind of organs which make up a monkey : Trill any number of rariations prorluce a single organ? If the beneficial improvement consisted in the modifica- 
tion of an existing organ, this might be the case, because the fact of the organ existing would prove that it was efficient, and so might maintain itself while waiting for the occurrence of all the beneficial variations which are to produce a completely improverl organ. But when there is no organ to begin with, a small beneficial variation can only be a rery small step towards the future organ, and will not confer any benefit of survivorship on the possessor. It will pass away with the other variations, which are either injurious or indifferent. 'This would certainly be our judgment in the case of any production of human ingenuity. Let us suppose, for instance, that the inventor of the compound steam engine, instead of completing the triple expansion machinery before he brought it in a finished condition to a purchaser", had said to him, "My invention will not work in its present unfinished state, but when it is completed it will become a valuable improrement." Wrould not the answer he would receive be, "A machine which will not work in its present state is of no use at all. Complete it, and if it then does better work than would be done without your new rariation, we will pay for it"? Is there any reason why we should not apply the same principle to the first steps of a tendency towards a future improved organ or an mnfinished improved animal ? The idea of an organ being generated by a number of accidental deviations in the offspring from the parent is entirely without parallel in our experience. The formation of a new organ requiles a neat and accurate fitting of the parts, which exclucles the 
random effects of chance. Our ancestors would have got over the difficulty by saying that reasoning from human works to those of Nature is fundamentally erroneous, because there is in animals a mysterious vital force, which works as human workmen camnot do. But the tendency of modern thought is to repudiate, is to deny, any such mysterious entity, and to regard the body of an animal as simply a collection of atoms, and the force governing it as consisting of the forces of these atoms; and it is of the essence of Darwinism to reject all mysterious forces and to account for the evolution of animals by known and admitted facts.

The Darwinian is in this dilemma. If he assumes the individual rariations to be small, a very great number of them will be required to produce an useful organ, if indeed it can be produced at all by any number of accidental variations. With the increase of the number will increase the number of generations during which the incomplete improrement will confer no superiority, and the risks that the series will not be carried on without accident to the point at which an useful organ is produced. If the number is diminished, each individual rariation will have to be supposed greater, and then it will have to be greater than the actual variations which we see around us, and on which the theory of natural selection is based.

Let us now examine the facts which have been adduced in support of the theory, or in answrer to the difficulties which have been alleged against it.

In this examination the place of honour is due to 
Wallace's defence of the application of Darwin's theory to the evolution of inportant organs, in his 'Darwinism.' The singular coincidence by which, while Darwin was working out his theor' in the 'Origin of Species,' Wallace was independently arriring at the same conchusion on the other side of the globe, makes the latter the lighest authority and the natural champion of the Darwinian doctrine.

In his section on the begimnings of important organs, he informs us, as has already been mentioned, that Darwin himself felt that the objections to their production by natural selection had great weight, and that it is almost impossible to conceive how the first rudiments of important organs can have been of any use, or how, if not of any use, they can have been preserved and further developed by natural selection. He then writes as follows:-

"Now the first remark to be made on objections of this nature is that they are really outside the question of the origin of all existing species from allied species not very far removed from them, which is all that Darwin undertook to more by means of his theory. Organs and structures such as those abore mentioned all date back to a very remote past, when the world and its inhabitants were both rery different from what they are now. To ask of a new theory that it shall reveal to us exactly what took place in remote geological epochs, and how it took place, is mreasonable. The most that should be askerl is that some probable or possible mode of origination should be pointed out in some at least of these difficult cases, and this Mr. Darwin has done." 
The reader will have observed in this passage that Darwin himself thought it almost impossible to conceive how the first rudiments and important organs could have been of any use, and, if not of any use, how they could have been preserved and further developed by natural selection. In truth, in a few words, Darwin has condensed the whole aroument of this chapter, and would have made that chapter entirely superfluous if he had not subsequently changed his opinion. With respect to Trallace's remark on the objection to the production by natural selection of important organs, that it is outside the question of the origin of existing species from allied species not very far removed from them, which is all that Darwin undertook to do, it is only necessary to say that, if Wallace correctly describes the object of the 'Origin of S'pecies,' this book has nothing to say against it. For the derivation of one species from another, formed so much on the same plan that naturalists consider the difference between them only "specific," will not require the prorluction of a new organ. It is when the theory of natural selection is held up to us as a complete explanation of the whole process of evolution from a few primeval creatures, without organs or structures, to the higher vertebrates, that the question is forced upon us whether it is adequate to this far higher and larger work.

Wallace then proceeds to cite three cases-the mammary gland, the peculiar position of the eres in flat-fish, and the eye.

The second of these is easily disposed of so far as 
the subject of this chapter is concerned. It is not the case of the production of a new organ at all. 'The flat-fish is born, like all other' fishes, with two eres, one on each side of the head. When it falls into its permanent position, by lying on its side, it screws round the eye which is undermost until it is brought to the upper side. It then has both eyes on the same side, contrar'y to the rule with all other fishes. This is Darwin's explanation. There is here no formation of a new organ, only a change in the position of an organ alleaty existing.

On the first case, the mammary glands, Nallace says Darrin remarks that:- -

"Tt is admitted that the ancestral mammals were allied to the marsupials. Now in the very earliest mammals, almost before they really deserved the name, the young may have been nourished by a fluid secreted by the interior surface of the marsupial sack, as is believed to be the case with the fish (Hippocampus) whose eggs are hatched within a somewhat similar sack. This being the case, those individuals which secreted a more nutritious fluid, and those whose young were able to obtain and swallow a more constant supply by suction, would be more likely to live and come to a healthy maturity, and would therefore be preserved by natural selection."

In all this there is no question of a new organ. Darwin begins with a marsupial sac alleady existing, and goes on to suppose that the fluid secreted by this sac was increased in quantity and improved in quality in some female, and so gave her offspring an 
adrantage over their fellows. It is only a case of an organ, the sac, being improved in efficiency ; and there is no intention in this book of denying that this may occur.

The third case cited by Wallace is the eye. He writes of it that it is the most difficult case of all, and that even to the last, Dar'rin says, the thought of it gave him a cold shudder. These extremely strong expressions, used by the two discorerers of the theory of natural selection, may induce an orthodox Dar'winian to regard with some indulgence the doubt of a semi-Darwinian on the subject. Tow Wallace asserts that the application of this theory can be shown to be not unintelligible-granting, of course, as he assumes, the sensitiveness of some kind of nerrous tissue to light. He states that in sereral of the lower animals we have rudiments of eyes consisting merely of pigment-cells corered with a translucent tissue, which may possibly serve to distinguish light from darkness, but nothing more. 'Then we have, he adds, an optic nerve and pigment-cells; then a hollow filled with gelatinous matter of a convex form, the first rudiments of a lens. That many of the stages of the process should be lost would, he says, naturally be the case oring to the great adrantage of each modification, which gave distinctness of rision in the animals rho possessed it inevitably surviving, whilst the others became extinct. But, he adds, we can well molerstand how, after the first step was taken, every variation tending to more distinct rision would be preserved till we reached the perfect eye of birds and mammals. 
In this summary and not rery distinct manner he pasies orer the ride interval betwcen gelatinous matter in a hollow and the eye, with all its parts so nicely adapted to receire rays of light and refract them on to the retina, and to produce in the brain the sensation of colonrs, and of the gradations of light and shade, which enable us to distinguish all kinds of objects, and by which animals are enabled to distinguish the animals they are to flee from or to attack as their prey. But there is another interpretation which may be put upon the facts. This is that there are two distinct kinds of perception, one which merely gives the sensation of light and darkness, the other which enables us to distinguish the nature and position and action of objects; that the gelatinous matter was the highest organ for the first, but that the other required a different and far higher structure-that which we may call the optical eyeand that this was no mere improvement on the gelatinous matter, but was produced in some other and independent manner.

He appears to suppose that there was first a period in which $n 0$ animals had the sense of sight, and in which, conserquenty, the whole animal creation were engaged in a sort of miversal game of hlind man's buff, in which the forfeit was, for the gramnivorous animal, the being caught and eaten, and for the carnirololis animal, the being starved for not catching him ; that then, in some individual, the nerrous sensitiveness to light became improved into a perception of light - a rery different thing. Now this must have occmrerl accirlentally, since natural selection does 
not provicle any cause for changes except accilent. That then all the details of the structure of the eye were added, also accidentally, mntil the eye, as an optical instrument, became capable of perceiring colours and shades, and so of distingmishing objects. That this taking place with some animals and not with others, the game of blind man's buff became an unfair one, an animal with eyes further adranced being able either to catch another who had not this advantage, or to escape from it.

Wallace seeks to minimise the interval between the hollow filled with glutinous matter and the eye as an optical instrmment composed of lenses fitted to refract the rays of light to a forus, and with a retina placed at the exact distance behind the lenses required for the reception of the refracted rays. Let us imagine a series of organs beginning with the hollow filled with glutinous matter on the one hand, and on the other the most imperfect eye which will give the perception of objects, and will, in some degree, give the possessor the means of distinguishing by sight between the animals which he will eat and the animals which will eat him; and let us then apply to the case the principle of progress by small accidental variations, and try to fill the interval with a series of organs each varied only by a small accidental rariation, and ret each giving to its possessor an advantage over its predecessor ; and he will see the difficulty of the problem.

Wallace, professing to deal with the eye in general, takes no notice of that very remarkable organ-the compound eye of an insect. Now this is an impor- 
tant branch of the subject, and one the explanation of which by natural selection appear's peculiarly difficult. The compound eve consists of a great number of minute tubes, in each of which there is a kind of lens. Te are told that in some of these eyes the tubes are counted by thonsands. Now whaterer may be the process by which this multitude of organs enables the insect to distinguish objects, it must be fundamentally different from that which, with our simple eyes, we use. The eye which Trallace molertakes to trace through all its stages is, in all, a single organ. If, then, the compound eye is to be derived from one of these stages, natural selection has to account for the sudden and fundamental change in its mode of proceeding. If, on the other hand, the origin of the compound eye is entirely different in its origin from and independent of that of our eye, natural selection has to find out this origin.

One feature which distinguishes the eye from all the other structures in the body is that it is formed in accordance with regular geometrical figures. If we suppose that intelligence was concerned in designing it, we should at once understand that this is due to the reason which induces manufacturers of telescopes, microscopes, and eye-glasses to form their instruments in geometrical forms - that is, they are acpuainted with the laws of optics. But, as chance knows nothing of optical laws, it is not easy to understand why forms produced accidentally and without any intervention of intelligence should conform to these laws. If there was no conformity, why should the nascent organ, which has resulted in the 
beautifully designed and skilfully executed instrument which we use, conform to them as carefully as if it had been designed by a mathematical professor, and executed by a very skilful workman :

In judging of the change required for the development of the optical eye out of an inferior eje, we must take into account the extreme complication of the former and the extreme nicety of the acljustments required. To display these qualities would be to write a book on the eye. But one little detail may be mentioned as a specimen. The crystalline lens, one of the structures, appear's a simple, structureless liquid, but on examination it is found to be a beautifully complicated structure.

Let us now examine some of the evidence which has been adduced in support of the theory of natural selection--not for the purpose of disputing its value, as respects the general theory, since that is not here controverted, but in order to see whether any of it applies to the question of the formation of nerr or gans. In order to prevent confusion between these tro objects it will be convenient to enumerate the different kinds of improvements by which the progress of evolution must have been carried on from the amoba to the monkey. They may be classed as follows:-

1. The general diminution and ultimate obliteration of some part of an animal which has ceased to be useful to it. The New Zealand Moa may be taken as one example of such a change, and the blind fishes who have long in habited dark caves are another.

2. The conversion of an organ formerly useful for one function into an organ useful for another 
function. The conversion of a fish's swim-bladter' into a lung, which, as naturalists tell ns, has taken place in animals whose residence has changed from water to land.

3. 'The change in the size either of one part of an animal, or of the whole animal, without the introduction of any new structure. Thus the series of the ancestors of the horse discovered by Marsh, of which the earliest was about the size of a fox, whilst the latent was nearly as large as our horse, is an example of increase of size; while for decrease of size we may compare the gigantic Edentata, which formerly inhabited South America, with the smaller animals of the same kind which are now found there. For variation in one part of an animal we may take the increased abmulance of hair in animals transfer'red to a colder climate.

4. The formation of a new organ. Of this class it is for the Darwinian to find an example.

It is only with this last class that we are concerned.

Now it is hardly necessary to state that there is no instance of a new organ haring been produced by natural selection in our time, or in an earlier age, up to the time when men first began to observe Nature - let us say up to the date of Aristotle's books on natural history. Since it has never been asserted that such a case has been found, a Darwinian will probably maintain that no argument cau be drawn from this absence of any such evidence, because the non-occurrence of any such inciclents may arise not from the inability of natural selection to produce a 
new organ, but from the fact that, in this late age of the world, every animal has got all the organs it wants, and therefore no new organ would confer such superiority as would enable him to surpass all his competitors in the struggle for existence. It is a fact that the remains of animals found in the rocks do not show us any case of the gradual derelopment of an organ from a nascent state to its completion, such as rould point to natural selection as its cause. But the Darwinian may fairly allege that the extreme imperfection of the geological record is a sufficient answer to such an objection. Still the fact remains that there is no evidence of an organ having been begun, carried on, and completed by natural selection.

But it may be thought that, though there is no suchì complete case known to us, we have eridence that natural selection has exercised so much formative power in modifying organs and structures that it may reasonably be infer'ed that it would have produced a new organ if the circumstances had been favourable. Let us therefore examine some of the cases in which it has shown this minor porer most strongly, $i$. e. the ancon sheep, the modifications wrought on the rock-pigeon by human selection, the variation in the length of birds' wings, the very interesting modifications in the ancestor's of the horse discovered by Marsh, and the peculiarities in the structure of the Archropteryx which indicate a transition from reptiles to the form of a bird.

The case of the ancon sheep is selected because it has been so often quoted as evidence in proof of the 
Darwinian theory. A sheep was born with forelegs much shorter than usual, and this deformity finding farour in the eyes of New England farmers hecause it prevented the sheep from leaping fences, it was allowed to live and propagate its peculiarity to offspring. 'There the improrement consister simply in the stunting of the fore-legs, which was certainly no proof of formative power'.

The case of the pigeon was greatly relied on by Darwin as a proof of the great changes which human selection conld work, the pigeon-fanciers playing the part of the law of the survival of the fittest. But this selection did not produce any improved structures. It only exaggerated into deformities certain parts of the bird, which, if the animals had been tmmed ont to pick up a livelihood for themselves, would have left them a poor chance in the struggle for existence.

The variations in the length of birds' wings is only the result of increased or diminished rigon of growth, which did not require the aid of any formative power.

The case of the ancestors of the horse loes not involve the action of any formative porrer to mould the fore-foot into a solid hoof. It only required that the centre toe, having more work thrown upon it, should attract more than its share of nourishment; while the others, having less work to do, should dwindle, and either become absorbed into the centre toe or hecome rudimentary.

The case of the Archaopteryx, strange animal intermediary between reptiles and birds, whose 
skeleton has been discovered, is an example of the class of improvements consisting in the diversion of an organ no longer required for one purpose, becoming useful for another. Here a fore-leg becomes useful for flight as a wing. Natural selection exerts the modifying influence which is admitted to be its function.

This chapter shall close with a curious paradox, which is presented by the working of natural selection regarded as the cause of all the organs which were not in the original primeval animal. It is certain that there is a powerful miversal cause which tencls to make the offspring copies of the parent. The have not to inquire here what is the nature of this cause. It is certain that it is an miversal fact. It is certain that its tendency is to produce exact copies. The small variations are certainly due to some minor causes acting in individual cases and disturbing the production of an exact copy. Now if these individual causes had not acted, the exactness of the copying process would have been complete. But if this state of things had here existed, evolution would have been impossible according to Darwin. For according to Darwin's theory every step in evolution has been the effect of some accidental imperfection in copying, all the imperfections being beneficial and so tending to survival. If there had nerer been a rariation, every generation would have been exactly like the previous one. If the first animal had been an amoba we should all have been amobre; if a moneron we should all have been monera. Whaterer superiority we 
possess orer those creatures we owe to an immensely long succession of failures-failures so far as the cause producing the copies are concerned. It is as if the Master of the Mint, insteal of working with a perfect machine, had had to work with one which frequently went wrong, and every time this was the case his mint tumed out much finer coins than when it ras copying strictly the original die. Different men will estimate the importance of this observation differently. An old-fashioned believer in a Providence would probably quote it as an instance of Providence orer'uling eren acciclents to produce improrement, till they produced the monkey. As it is we must, according to Darwin, beliere that the great general cause of offspring copying their parents, and all the little causes of the imperfection in the copring, had gone on in their blind unconsciousness till at length they blundered into the production of the monker.

The argument of this chapter may be summed up as follows:-

Darwinism undertakes to show that all the animals now living descend in lineal succession from parent to offspring from some amoba-like creature, for whose origin Darwin did not profess to account, without assuming the intervention of any intelligence to guide or direct the process. It, therefore, molertakes to explain how all the complicated organs and structures which make up one of the higher Nammalia were produced in the course of this wonderful erolution. Its system is based on two factors - the small acciclental rariations from the 
parental model which are found in the offspring of all kinds of animals, and the law of the survival of the fittest. It states that among these small variations there will sometimes occur one tending towards the construction of a new organ; and in some descendant inheriting the first rariation, another will occur with a further tendency towards the useful organ; and a third step will occur in a descendant of the first descendant, and so on, until at length the various partial stages will be consummated into the complete organ itself.

The result of the survival of the fittest has been that the animal possessing this organ had a somewhat better chance of surviving its competitors in the struggle of life and of producing offspring, some of whom inherited this organ, and the repetition of the process at length left animals endorred with it the sole survirors.

Now this book fully admits the frequency of small variations in all kinds of animals; but it asserts that it is not sufficient that they vary. It must be shown that they vary in the direction of new organs, and that the accumulation of such rariations completed the organ. Now it is asserted that the variations which we observe neither produce a new organ nor show any signs of tending to produce one, and that if from observation we turn to reasoning, an organ requires nice and accurate shaping Or' fitting of parts, of which we see no signs in the random deviations of young animals from their parents, sometimes in one direction and sometimes in another, such as we do observe. Moreorer the 
parts of an organ, when examined moler the microscope, are found to be composed of minute and delicate tissues and parts suited to the function which the organ is adapted to serve, but which we should look for in vain in the young animal.

Then as respects the second factor which is to complete the ascent from the amoba to the monkey-the survival of the fittest-it is admitted that if an inclividual appears in any kind of animal endowed with a new useful organ, of which its companions are destitute, the law will give it a chance of surviring its fellows, transmitting the organ to some of its descendants. But the Darwinian principle is that the organ is only completed after a long series of small changes. Now during these stages the possessor will not derive any benefit from the imperfect work which he is carrying about. It is only when the organ has been connpleted, or is at least very near completion, that it can begin to be of use. In fact, while the process is proceeding it will be rather a disadvantage than a benefit to him, because it will be an useless burthen, and will draw off part of the nourishment which might have served for the general service of the animal.

Take as an illustration the case of electric fishes. Now that they are in full possession of their electric batteries they doubtless enjoy the full benefit of the law of survival of the fittest, for 110 carnirorous animal who has once touched them will try the experiment again. He will rather prey on any other inhabitant of the water. But let us go back 
to the time when Nature once thonght of adding to her other anticipations of human ingenuity the trade of manufacturer of electrical batteries. How long a time must the installation have taken if the ordinary flesh and nerves of the fish had to be converted into the materials of the battery, and the battery itself be constructed - if all this was to be done by the Darwinian method of small variations, occasional occurrence of a beneficial variation, and no exercise of intelligence by anyone to be allowed to gruide and accelerate the process. One is afraid to estimate through how many generations of fishes the accumulation of small variations must have gone on before the machine was completed, eren if we admit that by the Darwinian method the rork would ever come to an end. And during all this time the unfortunate fish must have been dragging about this: heary encumbrance (we are told that one third of: the body of the Gymmotus is occupied by his: battery), which did him no good, and impeded him alike when he tried to escape from the marine animal who wished to eat him and when he tried to catch the little fishes whom he wished to eat (ree in Chapter IX Huxley's modification of Darwin's theory on the formation of new organs). 


\section{C'HAP'TER VIII.}

\section{On Trstinctio}

VEs give the name of instinct to the actions of animals when they are beneficial either to the animal or to its offspring, or in the case of animals living in community such as bees or beavers to the community, when the circumstances are such as exclude the idea of their being caused by the animal's intelligence. 'T'wo reasons generally induce us to ascribe an action to instinct - when all the animals of the same kind perform them in the same manner, or when they are performed by animals who, either from extreme youth or from the circumstances of their position, have never had the opportunity of exercising their intelligence on the subject matter with which they have to do. Instinct plays so large a part in the conduct of all animals excepting man, that no theory of evolution can be regarded as established which does not account for its origin. Darwin's theory was that the actions which are now performed by instinct were originally produced by intelligence-that in the beginning some animals were sufficiently intelligent to discern a beneficial result, or the means by which it was to be attained, and that they acted accordingly; that, by the 
frequent repetition of the same action, permament impression was made on some part of their being, probably the brain or nervous system; that this impression was transmitted to their offspring and caused them to perform the same actions without the use of intelligence which their parents had practised through intelligence; and that this impression constitutes instinct. As Darwin nerer developed his views on this subject, it becomes necessary to state them in these very general terms, lest we should introduce any ideas which he would not have approved. Now this theory would be at once rejected by Weismann and all those who follow him in denying the hereditary transmission of acquired faculties. But I suppose others rould admit the possibility that an animal which has learnt to perform a certain action, and has practised it till it has become a habit, may transmit the habit to its offspring, and they may in turn transmit to all their own offspring. How the transmission takes place is a mystery. Take the case of chickens, who, as soon as they are hatched, rm about picking up food as if they had learnt to do so by experience stimulater by hunger. The manner in which the habit is acquired by the parent is supposed to be that the frequent repetition of an action produces some molecular change in the brain or nervous system, which causes these parts to imitate the same action even without the intervention of intelligence. But how this permanent change in the parent can be transmitted to the ego, which certainly has no brain or nervous system, and from 
the egg to the chicken, must be acknowledged to be a mystery. But when this has been admitted, there remain other difficulties to be dealt with in the way of Darwin's theory. First, the high degree of intelligence which we must suppose in the individual of any kind which was sufficient to find ont or practise some of the actions, which were afterisards to become instinctive. Then if the action was of such a nature that it was necessary for the preservation of the animal itself, there was the danger that the whole first generation of animals would perish before they had hit upon the precantion or method which was to preserve them. But the greatest difficulty arises in the cases where the action is of no use at all to the animal which practises it, but is necessary for the preservation of its offspring. Such is the case with oriparous animals such as birds, and a great part of insects. This applies to the cases in which the mother bores a hole and deposits one or more egg's in it, and in some cases deposits with the egg's food for the future insect. If it is attempted to account for this by maternal affection, this implies that she knows that the egg will produce a living insect, and it has to be shown how she obtains this knowledge.

It also assumes this feeling of affection and necessitates the explanation how the feeling arises in the mother', mless it was implanted in her by sone superior power. It is also very difficult to reconcile this with the absolute indifference which she shows to the fate of the yomng from the moment when she has marle the deposit. 
The case of the Sphex may serve to exhibit all these consilerations.

The Sphex, an insect allied to the wasps, hollows out at the end of a long passage three or more chambers, and deposits an egr in each. She then captures a supply of insects to serve as food for the larve who are to proceed from the eggs. Different species of Sphexes catch different kinds of insects for this purpose-crickets, spider's, beetles, and caterpillar's. But each species always confines itself to one kind of prey, which it stings so cleverly as to paralyse, without killing it, so that the victim can live for weeks. When it is a spicler it is stung through the central ganglion, in which most of the nerrous matter is aggregated. When it is a beetle it is thrown on its back, and is then pierced by the sting through the main nerve-centre, between the first and second pairs of legs. When it is a cricket or grasshopper it is stung three times through the nerve-centres. A grasshopper will live for six weeks or more after the operation. When it is a caterpillar a series of from six to nine stings are given, one between each of the segments, and its brain is then partially crushed by the Sphex with its mandibles. Romanes thinks there is not much difficulty in accounting for the facts when the rictim is a spider or a beetle. But he acknowledges that the case is certainly very different with the cricket and the caterpillar. For here--at least in the latter. case-we encounter the extraordinary and mavoidable fact of an insect, without any guiding or mechanically imposed necessity, instinctirely choosing 
a number of minute points in the miformly soft body of its prey, with an apparently rery precise knowledge that it is only at these particular points that the peculiar paralytic effect of its sting can be exercised. He states that he feels it to be the most perplexing case which has yet been brought to light, and the most difficult of explanation upon the principles of the Darwinian theory. He can see no alternative but to conclude that the wasp-like animals owe their jnstinct to the high intelligence of their ancestors, who found from experience the good effect of stinging caterpillars between the segments of their bodies, and consequently practised the art of so stinging till it became an instinct. Romanes, in an appendix, returns to the question of the cause which first determined the ancestors of the Sphex to sting their prey in only nine particular points; and says that Darwin's answer to this question is as follows:-

"I have been thinking about Pompilius and its allies. Please take the trouble to read on perforation of the cololla by Bees, p. 4.5 of my Crossfertilisation to end of chapter. Bees show so much intelligence in their acts that it seems not improbable to me that the progenitors of Pompilius originally stung caterpillar's and spiclers, etc., in any part of their bodies, and then observed by their intelligence that if they stung them in one particular place, as between certain segments on the lower side, their prey was at once paralysed. It does not seem to me at all incredible that this action should then become instinctive, i. e. memory transmitted from 
one generation to another. It does not seem necessary to suppose that when Pompilius stmng its prey in the ganglion it intended or knew that its prey would keep long alive. The development of the lar'væ may have been subseruently modified in relation to their half-dead, instead of wholly dead prey; supposing that the prey was at first quite killed, which would have required much stinging. 'T'mm this over in your mind," etc.

We have here, then, the explanation which Darwin himself would have given, if he had been challenged to show the application of his theory to the case. Let us follow the advice given in this letter, and turn it over in our minds with all respect to its author. Romanes does not seem to have been quite satisfied with the explanation, as he concludes by saying that it is very desirable that the facts should be further investigated, as the result might be that some clue would be given to the origin of the instinct.

The first observation to be made is that all the difficulties which are suggested in the chapter on the mystery of reproduction with respect to the insects which make a hole and deposit their egas in it, apply to the conduct of the Sphex. Why does she mindertake the labour of excavating the passage and the chamber to which it leads? Does she know that she is going to shed ego's which, if properly protected, will grow into larvæ, and that these will require a large quantity of food, and if this is provided will form themselves into cocoons, which will in turn form themselves into Sphexes like herself : Treknow all this because we have observed and studied the 
varions changes which the egg's mndergo. But the Sphex, which flies aray as soon as she has deposited the eggs and appears to have lost all interest in then, cannot know all this. Supposing she did know something of this, why should it lead her to care for them mnless she had acquired the maternal instinct, and how conld she acquire this mnless it was implanted in her by some superior power? These remarks apply still more strongly to the additional labour undergone in storing the chamber's with food which is of no use to the eggs, and which is to be consumed by larve which the Sphex has never seen, and which, so far as we know, would not be recognised by her if they were shown to her.

We then come to the extraordinary precaution taken by the Sphex of rouncling the caterpillar in such a way as to destroy its porrer of motion or resistance without affecting its rital power's. Darwin suggests that the ancestors of the present Sphexes had aconired the habit of stinging the caterpillar in or'ler to kill her, but that they were so intelligent that they observel that when the stings were applied to particular points the creature became motionless, but remained alive; whereas, when they rere directed to other points, either the caterpillar died or retained the porrer of moving to escape or struggle. Tn other words, they distinguisher between immobility resulting from death and immobility the result of paralysis. This seems a very fine distinction for an insect to draw. But how dicl they also draw another distinction between the effect of the two kinds of immolility on the preservation for 
consumption-that when death was the cause putrefaction took place, but not when paralysis was the cause?

Darwin refer's to the humble-bee's practice of perforating the corolla of a flower to get at the honey, which points to the display of a certain amount of intelligence by that insect, but not so much as we are asked to ascribe to the first Sphexes. When the humble-bee bites a hole in the side of the corolla of leguminous flowers, it only bites throngh the standard petal, and always on the left side just over the passage to the nectar, which is larger than the corresponding passage on the other side. This shows intelligence. But the bee is pursuing its regular course of entering flowers in order to steal their honey, and knowrs the honey is in the flower. When a burglar finds himself in front of a locked plate cupboard, he does not require high intelligence to teach him that the shortest way to get at the plate is to cut a hole in the door. As for the preference for an entrance which will bring him by the shortest road, we may suppose that the bee, in its first attempt, did not hit upon the best point, but after entering flowers a few times found the easiest route, and afterwards adopted that until it became an instinct. The Sphex, on the contrary, when she makes her singular arrangements for the benefit of her unborn children, is doing this for the first time, and has no time for trying experiments as to the best mode of action; and this, it would seem, must always have been the case. As for the Sphexes of the present time, their careful and painstaking 
observer, Monsiem Fabre, has decided the question whether they are guided by intelligence or instinct, for he has ascertained by experiment that they go through a series of actions in a certain order, from which they will not depart even when his interference has made adherence to it absurd.

From the above it appears that we have to account for the existence in the mother Sphex of a strong maternal affection for the creatures which are to be developed out of the eggs, or, at least, of a strong feeling impelling her to provide for the hatching and nourishment of the future insect, which is so difficult to reconcile with the absolute indifference she displays from the moment when she has deposited them, that in the chapter on the care for offspring the word affection has not been used, but a word which implies no theory concerning the nature of the mother. Then it is necessary to explain how she acquires the information that the contents of the egg will turn into an insect requiring fook. 'Then she must be clever enough to hit upon the plan of carrying insects of certain kinds to the chamber containing the eggs. 'Then she must learn that these rictims will become unfit for food by dying, and the art of wounding them in such a way as to keep them helpless, motionless, and yet fresh. This last and crowning act of affection is not to be lightly regarded, since in all the accounts of human ingenuity and cruelty practised on animals I cannot recollect any invention for keeping them in a state of suspended animation till some one is ready to eat them. It also requires that the maternal Sphex 
should first learn that the diet of cold grasshopper or cold caterpillar was disagreeing with its new-born children, and that warm meat would suit them better-a difficult knowledge to acquire since she never goes to the chamber in which they are pining for fresher meat. A Darwinian may perhaps admit that the acquisition of all this knowledge would be too much for one Sphex to acquire, but it suggests that one female may acquire the maternal affection; one of her descendants may learn that the eggrs are destined to develop into young Sphexes and objects of her affection; another descendant may conclude that the young ones will require food; and so on to the crowning discorery that a wound in one precise spot will keep the victim in a state of suspended animation. But although this arrangement may suffice for the gradual education of the mother, it will certainly not be sufficient for the young ones, who in each generation will want their fresh meat, and not get it till the education is completer.

The case of the burying beetles may also be quoted as an example of the powerful impulse which the course of instinct, whaterer it is, has exerted upon a particular species of insects. The male of these creatures seeks till he finds the body of a dead mouse or mole; he then buries the carcase by withdrawing the earth from under it. Now, as the female does not assist him-she is only an inch long-it may be seen what perserering exertions must be required for such a small creature to succeed in accomplishing the work, especially as he 
sometimes has to drag the body some distance to a place which he judges suitable for the burial. The female then deposits her eggs, and haring thus provided for the nourishment of the future romg', as the Spliex for hers, she goes away. If we imagine a man mulertaking to drag the bodies of tro full-grown elephants without assistance some distance along a road, and then to dig away the earth from under the bodies till they fall into a hole, and to do all this without any hope of deriving any benefit from the feat, we shall have some idea of the case. Let us now go back to the ancestors of our burying beetles, who, as we are asked to suppose, are employed in rorking out by their intelligence this singular invention; we shall see how large a demand we must make on their intelligence and their energy in order that they should impress the whole process upon the brain of their children as an instinct. 


\section{CHAPTER IX.}

\section{Huxley's Suggestion of the Formation of New Organs by Larger Advances.}

We have seen in an earlier chapter that Huxley urged upon Darwin that he should not depend entirely on his theory of natural selection by small accidental variations, but supplement it by supposing an occasional larger variation. T'o use Huxley's words, Darwin was to consider Dame Nature as occasionally making a jump towards the construction of the organ, or the sudden occurrence of what gardener's call a sport. It may appear to some readers that Darwin would have done well if he had acted upon his friend's suggestion, and that he might then have made out a better case in favour of his theory as applied to new organs.

We have no record of the arguments which Huxley used in his discussions with his friend on this point, but we may fairly suppose that lie doubted whether small variations, however numerous, would produce a new organ with all its structures, and, in particular, saw that one small variation could give its possessor no superiority in the struggle for existence, and so cause the animal to survive its fellows and transmit the variation to 
its children, and that the variation, not accomplishing this result, rould pass away like the numerous useless rariations without haring contributed anything torards the construction of the future organ. It is probable also that these considerations contributed to confirm him in his carefulness not to commit himself to a belief in Darwin's theory of natural selection. If Darwin had accepted the suggestion, the adrantage to his argment would have been obvious, for where a small variation would not give the requisite superiority, it would only be necessary to suppose Dame Sature to hare made one of her jumps at that point, and the progress towards the complete organ might be accelerated as much as might be required. Darrin persisted in rejecting the suggestion, and we may see strong reasons for his decision. In founding his theory on the occurrence of small rariations, he founded it on an undoubted fact. He began with a reve causa, and had only to show that it was arlequate to produce the effect. But if he accepted the aid of jumps he might have been called on to prore that such phenomena actually took place, and the sports observed by gardeners might not have been sufficient to show that a rariation amounting to a great advance towards an organ might occur. Besides, he might have been called on to explain how an animal became possessed of the porrer of producing a greater step torards a ner organ than observed facts will support.

For the jump might have to be considerable, if it was to accomplish the result of giring the individual 
a sensible superiority over his fellows. To illustrate this let us take the case of the descent of monkeys from an ancestor of the quadruped type, and to simplify the inquiry let us confine it to the gradual change of the quadruped's fore-legs into the tro hands of a monkey. According to Darwin, this improvement was accomplished by an extremely large number of small variations spread over a rery long period. During this period the limb was gradually changed from a leg fitted for rumning $\mathrm{Or}^{*}$ walking on the ground to an arm fitted for grasping a branch of a tree, and climbing on to it. During the process it would become at every stage less fitted for rumning away from a beast of prey, while it would not, till quite late in the transformation, be available for grasping and climbing; it would be only late in the process that it would become able to escape from him by climbing a tree. There would be a long interval during which he would be neither a fit quadruped nor a fit monkey, and according to the law of the survival of the fittest would be condemned to be exterminated in favour of animals who were fitted for some one form of life. Here Huxley's suggestion of a jump would come in very opportmmely to shorten this intermediate period. But it would have to be large enough to cover a great number of Darwin's small variations. But then the hypothetical jump would imply a great formative power in the organisation, and also, as it seems to me, the intervention of intelligence to guide this porrer to its end correctly. From Darwin's persistent determination not to 
accept the aid of Dame Nature's jumping powers, but to stick to his small accidental rariations, we may infer that his theory would lose more than it would gain by the introduction of the new resource. It would certainly have been very convenient, if a difficulty occurred in the course of his arguments, to make Dame Nature jump high enough to clear it.

In 'Darwiniana,' the second rolume of Huxley's collected essays, the following passage occurs:-

"These considerations lead us further to see the inappropriateness of the objections raised to Darwin's theory, on the ground that Natural Selection does not account for the first commencement of useful organs. But it does not pretend to do so. The source of such commencements is necessarily to be sought in different variations, which remain unaffected by selection mil they have taken such a form as to become utilisable in the struggle for existence." **

Huxley's assertion that it ras never pretended that Natural Selection would operate before an organ had become sufficiently advanced to be useful, does not agree with the treatment of the first begimnings of organs by both Darwin and Wallace. 'They both speak of the difficulty of accounting for' the first beginnings of organs, and undertake to solve this difficulty by argument drawn from Natural Selection, and they do not suggest any other way of explaining it. But let us leave this subject of Darwin's opinion and examine Huxley's own solution. * “Darwiniana," by 'T. H. Huxley, 1893, p. 290. 
Let us sappose the first small acciclental valiation in an animal, which, if transmitter to its descendants, and followed by a hundred other variations, are to produce the required organ. A hundred rariations seem an extremely inalequate allowance for the complete construction of, let us say, an electric battery, filling a large part of the body of rymmotus electricus. But it will be sufficient to illustrate the argument. Huxley assumes that this variation will be transmitted to a series of descendants without impairment, down to the one animal in whom the nascent organ is to be sufficiently advanced to be useful. But why should this one variation be thus preserved through all the other variations which will be continually occurring; any more than any other one of them? It camnot be because it is useful by the law of the survival of the fittest, for Huxley assumes it to be useless. I can only see one justification for the assumption, and that is to assert that all rariations are permanent by some natural law, and this one among the rest. But this is contrary to what we know of small accidental variations, viz. that they are varying sometimes in one direction and sometimes in another, and so succeeding and obliterating one another. Indeed, this appears to follow from the definition "small and accidental." What will be the nature of this first variation? It will be a little lengthening" or shortening of a part, or a little thickening or thinning of a part, or a little deviation from the shape of the parent part, or some other little change equally insignificant. If one particular variation is 
to be continued, there must be a permanent cause for it, such as an intelligent person intervening. This Huxley would rehemently deny. Or there must be an existing habit in the animal's constitution. But this camnot be, since this rariation is assumed to be the first morement of nature towards the manufacture of electrical batteries. This argunent rill be similar in the case of the next variation, which is to contribute to the construction of the organ. That variation will be merged in the general variety of variations, and the same argmment applies to the subsequent stages. The conchision appears to be that the stage of usefulness, at which the survival of the fittest is to begin to take effect, will nerel be reached.

\section{POSTSCRIPT.}

The preceding chapter was written before the appearance of Sir E. Fry's two articles in the 'Monthly Rerier' for December, 1902, and January, 190:3, on "The Age of the Inhabited World and the Pace of Organic Change," in which he collects a number of cases of sudden and permanent changes, amounting to the production of a new species of flower. His first case is that of the toadflax (Limnin mlycurs), a single specimen of which was brought to Limnæus, and of which other speeimens have occasionally been found in Germany and at Brigg, in Lincolnshire. Fry also quotes De Vries, of Amsterdam, as having produced a number of varieties of flowers, some of which would be suffi- 
ciently different from the parents, and breeding so true, that they would be reckoned as natural species. 'These facts appear' to justify Huxley's opinion as to the importance of sudden considerable variation in plants. But it must not be too hastily concluded that Darwin was wrong in persisting in relying more on his small variations. It would be necessary for his purpose not only that considerable variations should occur, but that they should be beneficial, so as to enable the plants in which they occurred to survive in the struggle for existence and supersede the unmodified plants. But it does not appear that the peloric sports mentioned by Sir E. Fry have superseded, or are superseding, the regular plant. They continue to be-what they have been from the time when they were first observed - a variation only appearing occasionally, and not interfering with the normal plant. The inference to be drawn from their appearance seems to be that some plants carry abont with them and transmit to their descendants a power of produeing two kinds of flowers-the ordinary kind and a second kind-and that this power oecasionally breaks out and produces the second kind, from causes unknown to us, but that, as the second form is neither much better nor much worse than the other, it will continue to be what it is-an oecasional eccentricity.

Howerer this may be, then, the argment of this book is not affecter, as there is no suggestion of suditen considerable changes in animals. 


\section{C'HAPTER X.}

\section{ON Eifo'trio Fishes.}

Thes case has heen quoted by way of illustration in a previous chapter. Here it will be discussed more fully.

The case of Electric Fishes is specially instructive for three reasons.

1st. Tt has furnished an answer to an argment which has been montioned in the chapter on the formation of new organs as one which might be used on the side of Darwinism to acconnt for the fact that we do not find new organs in process of being formed in the animals of the present day. The argument is supposed to be that in this later stage of evolution all animals have all the organs they want, and therefore no new one can be produced in an animal which will give him an advantage over its competitor in the struggle for existence. Whatevel may be thought of the value of such an argument in other cases, it certainly does not apply to the case of electric organs in fishes, for the atrantage of these is the protection of a fish from more powerful fishes, who would 
otherwise cat him; this is Darwin's statement. He adds, more doubtfully, that it may assist the more powerful fishes by paralysing the smaller fishes whom they may wish to eat. Now as only a small number of kinds of fishes possess the organ, while an immense number of kinds are without it, it is clear that there must be very many among the latter which must be as much in want of it for their protection, and perhaps also for paralysing their prey, as those which possess it. The force of this argument will be best appreciated by those who consider how the whole life of most fishes is spent in eating other fishes and trying to escape from being eaten by them. Therefore if Darwin's principle of the accumulation of small variations and the surviral of the fittest is sufficient to account for the possession of the organ by the few which have it, the same cause ought to be now acting in some at least of the immense majority which are equally in want of it.

2nd. It has happened that men of science, cultivating the science of electricity, have in the comser of their investigations inrented and constructed electrical batteries contrived on the same principles that Nature had already applied for the benefit of a fer faroured fishes, although certainly they had no idea that they were only copying Nature's arrangements. We have, therefore, the advantage of comparing their methods with the method by which she has alpeady arrived at the same result.

3rd. Darwin had considered the case of electric fishes, and must certainly have felt the strongest 
desire to prove that his theory of natural selection would account for their peculiar organ. In his section on the special difficulties of the theory of natural selection, he virtually acknowledges in the following passages that he was mable to remore them by the application of that principle in the following case :-

"The electric organs of fishes offer another case of special difficulty ; for it is impossible to conceive by what steps these wondrous organs have been produced. But this is not sumprising, for we do not even know of what use they are. In the Gymmotus and Torpedo they no doubt serve as porrerful means of defence, and perhaps for securing prey; yet in the Ray, as observed by Mattencci, an analogous organ in the tail manifests but little electricity, even when the animal is greatly irritated; so little that it car hardly be of any use for the above purposes."

He then goes on to a suggestion of Dr. Ratcliffe, though without committing himself to its adoption, that the discharge from the battery of the torpedo may be one particular form of discharge which follows every action of muscle or motor nerve. 'This supposition, howerer, will not account for the elaborate structure of the 'Torpedo's battery, for the arrangement by which the animal can produce the lischarge at its pleasmre, and for the riolence of the electric shock which it can give-symptoms that the battery is an organ of first-rate importance, and strongly suggesting intention in its production. Darwin then concludes that we camnot at present 
go further in the way of explanation. Tn short, he declines to make any attempt to deal with the problem.

This, from a writer in general so ready to grapple with difficulties and objections, shows how rery strongly he felt the peculiar difficulties in dealing with this case. As far, therefore, as he is concerned we may consider him as having abandoned the attempt to account for this electrical organ by natural selection. But the present generation of Darwinians may not be willing to make the same concession, and may think that they can find a solution of the problem which he left unsolved. The facts of the case shall therefore be first stated, and then the difficulties which they appear to present.

Two kinds of fishes-the Torpedo, a flat-fish in the Old World, and the Gymmotus, a large eel in the New-are provided with a powerful electric battery, capable of giving a shock strong enough to kill a small animal or stun a man. A few other marine animals also possess batteries of more or less power, but as Darwin has selected the Torpecto and Gymnotus, to avoid complication they will be considered as representatives of the class. These batteries are composed of a great number of parts-we are told of hundreds of columns and thousands of laminæ, besides a multitude of nerves and bloodressels. The use of this battery is as a clefensive weapon to be discharged against any carnirorous fish which may attack them, and perhaps to stum any smaller fish which they may wish to eat. 
Darwin speaks more doubtfully of this latter use.

It happens that men of science have also for their own purposes invented and constructed a machine, the galvanic battery, for calling into force and action the power of electricity. They can therefore explain to us how their predecessors first arrived at the production of their battery. It is the usual history of human inventions. A man who had applied his intelligence to the science of electricity formed the conception of such a machine. He had studied and worked out in his mind all the details, and then handed over the plans to an intelligent workman, unless he worked with his own hands. Everything was done by intelligence, and conld not have been done without it. When, therefore, we are told that in the case of the other machine, which was added to the vital apparatus of the fish, made on the same principles, and adapted to a similar purpose as the galvanic battery, intelligence has had nothing to do with it, we are naturally startled; and our surprise is increased when we are told what is to be substituted for intelligence, vi\%. a long succession of accidental variations - in fact, a succession of accilents, withont any guiclance, intention, or intelligence. At least, this is the effect on my mind. But let us look into this alleged cause more closely.

For this purpose let us go back to the first fish in whom a small rariation appeared, which, if it was followed by a sufficient number of other variations of the kind required, was to produce a complete 
electric battery. As only a few kinds of fishes possess such an appendage, while the immense majority have nothing of the kind, nor even an approach to it, the parents of this fish must have been equally in this condition. Here one would wish to know the nature of this first step, and how far it went in the direction of the battery. The answer would certainly be, that we know nothing. about it as it occurred a long time ago. The answer would be the same with the second step and the third, and so on to the last step, which is to be a complete battery. We must therefore content ourselves with the vague expression used by Darwin, "a small step." One would also wish to know how many of these steps have intervened and are supposed to complete the battery. But on this point also no answer can be expected. We have therefore no opportunity for seeing whether the nature of the steps and the number will account for the production of the battery. In this account of the construction of the organ it is tacitly taken for granted that at the occurrence of each new step all the previous steps have been preserved and accumulated. But have we any reason for expecting this? Natural selection, indeed, teaches that all beneficial variations will tend to be preserved, because they will give the possessor a better chance in the struggle for existence, and so give him a somewhat better chance of surviving and transmitting to some of his offspring this variation. But this better chance can only arise when the variation is so far forward 
towards the completion of the future organ as to be able to do the work of the organ more or less well. In the present case this means that the variations must have produced something that will give electric shocks. But how many of the small variations must have occurred in the first fish and in his descendants before they will have produced something that will do this! Up to that time every rariation will be useless to the fish who acquires it, and will share the fortunes of all other useless variations - that is, it will not be preserved. This appears one of the weakest points in the theory of natural selection when it is extended to the production of new organs. It may be said that no notice has here been taken of the doctrine of the survival of the fittest, which was adopted by Darwin from Mr. Spencer as a part of natural selection. But this only means that the fish in question is more likely to survive than his fellows because it possesses some present adrantage in the struggle for existence-not that he will survive because he carries with him something of no use to himself but which will benefit his descendants.

The above reasoning will be made clearer if we suppose the case of a man who is going to a savage country, where he will want, for the protection of himself and his property and life, some weapons. If a pistol was offered to him complete with barrel, lock, and a box of cartridges, he would accept it gladly. But if a friend offered him the barrel of a pistol without the lock, or the barrel and lock 
without the cartridges, he would say an mnfinished pistol is no weapon at all.

The case is one to which Huxley would have applied his recommendation that Darwin should make Dame Nature occasionally take great jumps, so as greatly to shorten the stage during which the variations would be incomplete, and therefore useless. But it has been pointed out in an earlier chapter that Dar'win had strong reasons for keeping the dame to his pace of short steps. Besides, before discussing Huxley's idea it would be necessary that Darrinians should adopt his doctrine as a substitute for Darwin's, in order that they should accept the objections as well as the adrantages which his method presents.

If natural selection has been a sufficient cause for the production of an electric battery, how has it happened that among the immense number of fishes it has nevel produced anything like the batteries which are now possessed by a fer. All of these creatures, which are liable to be seized and deroured by other fishes, or other animals stronger than themselves, are as much in need of an electric battery for their protection. As for the preliminary steps during which the battery is being formed, the arguments against them will be neither' stronger nor weaker when extended to all fishes, than when applied to the present electric fishes.

Darwin refers us to observation of nature for proofs of rariations in animals, and observations can prove his assertion of their frequency. But what sort of rariations do we observe? We ob- 
serve variations in length, in breadth, in proportions, in external shape, in coloms, in other details. But do we ever find in an animal a great number of new parts, all exactly fitted to one another-all joined together into one living machine, and all evidently fitted to perform a certain function? Now this is what we find in the electric battery, and, until we do find such a process going on in nature, we cannot quote the little variations which we do see as any precedent for the production of such a battery.

Darwin is reported to have made a statement in conversation that, whenever he was employed in tracing the origin of an organ in one animal in accordance with the theory of natural selection, he found that an imperfect form of the organ was already in existence in some other kind of animal. Evidently his inference was that the imperfect form represented one of the stages through which the organ had passed in the ancestors of the animal now possessing the complete organ-and that this was an argument in favour of natural selection. It may be admitted that, although the occurrence of the organ in an imperfect state in some other animal is not conclusive evidence that it existed in the ancestors of the animal possessing the complete organ, it does suggest that this was the case. It is, therefore, unfortunate that Darwin never published a list of the cases in which he had observed the fact. We may conjecture that one case in such a list would have been that of poisonous snakes, whose apparatus may be divided into five parts- 
the secretion of a poisonous liquid, the bag which holds the liquid, the mobility of the poison tooth, the channel along this tooth which conducts the liquid along its length into the wound made by the tooth in the victim, and the provision by which the liquid, though a deadly posion to all other animals, is quite harmless to the snake itself. Now, of these conditions, two are found in an imperfect state in harmless snakes. For in some of these the salira is acrid and disagreeable, and, though not generally deadly, may perhaps be injurious to a small animal. And there is a tendency in the teeth of some harmless snakes to curl up sideways and thus form a groove, which, if the movement were carried further, might form a channel. But the other features of the arrangement are peculiar to the poisonous snake. But, however this may be, there is one organ to which Darwin's remark cannot apply. This is the battery of electrical fishes. For this may be asserted, not only because no naturalist has ever discovered the existence of any imperfect form of this contrivance in any animal outside of the small number of creatures who possess it complete, but also because when Darwin acknowledged the impossibility of explaining the origin of the organ by natural selection, he could hardly have failed to mention the existence of an imperfect form of the organ in another animal as a clue which might guide us to further knowledge.

While the battery was being formed in a race of fishes, up to the stage at which it became capable of giving a shock, it must have been a great dis- 
adrantage to the fishes by diverting a considerable part of the fishes' nutriment and nervous energy, and by giving it a useless burthen to carry. Therefore instead of the law of the survival of the fittest telling in the creature's favour, it would operate against it by the condition of its competitors more favourable than its own. 


\section{CHAPTER XI.}

'Two Arguments of Darwin against the Theistic Argunent from Design.

Is Darwin's concluding remarks to his work on Animals and Plants under Domestication he supposes a fall of rock from a precipice, and the fragments strewn on the ground at the base. He then supposes that an architect erects a noble and commodious mansion without any use of cut stone by selecting from these fragments wedge-shaped stones for the arches, elongated stones for the lintels, flat stones for the roof, etc.; and he sees the same relation between the fragments and the edifice as is borne by the fluctuating variations of each organic being and the admirable structures ultimately acquired by its modified descendants.

Now this supposition of a noble and commodious mansion being constructed out of the fragments into which a mass of rock has been broken by a fall, without any cutting of any of these into more regular shapes, is contrary to all experience and 
probability. Any architect would at once decide that nothing could be made out of these fragments of stone alone beyond some very rough rubble work, and that if a house of any kind could be built with materials so incapable of fitting together with exactness, it could only be by adding a new material-mortar or cement of some kind-and using this liberally to fill up all interstices and consolidate the whole into one mass. But to produce a building deserving the description of a noble and commodious mansion much more would have to be done. The architect, that is an intelligent being, would have first to form a design ; then to collect a number of masons and other workmen, that is intelligent being's, to bring to the ground all requisite tools and machines, mortar, timber, and all other indispensable materials; then to set these other subordinate intelligent beings to work under his direction to pick out of the fragments of rock those which could be cut into the exact shapes required (assuming that they were of a kind of stone capable of being so cut); and finally to cause the men under his direction to perform all the skilful processes by which a mass of heterogeneous materials are formed into a complete and noble structure. In short, the whole work would consist essentially of the application of intelligence to carry out a designn.

So completely is this the case that the Theist would desire no better illustration of his argument than the instance which Darwin brings forward to illustrate his theory of natural selection without intelligence. According to the former, God is the 
supreme Architect, as He was called 2000 years ago, who has designed and intended all the innumerable structures which we see in animals and plants. 'There is, indeed, the difference that whereas the human architect, possessing only extremely limited strength, is obliged to resort to other minor intelligences called workmen for the execution of his intentions, the divine Architect is conceived as powerful enough to carry out His intentions without the assistance of inferior intelligences. But the argument certainly does not lose any force by this distinction.

It may be added that if Darwin's supposition could be verified, so that the noble and commodions mansion could be constructed by an architect out of the fragments of the rock alone without any other materials and without any shaping of the fragments, the theistic argument would have to be raried in expression, but would not be weakened. For, if an architect were found capable of producing such a result with such bad materials, the intelligence which he would exhibit would be so extraordinary that the necessity for intelligence in architecture would remain at least as strong as before.

Darwin's second argument is this:-If we insist that all the useful structures which we observe in animals and plants imply a divine design, we cannot deny that all the useless variations which man has fixed upon for his amusement or for bad purposes were also intended to produce these effects. We must, it appears, acknowledge that the variations in the crop and tail feathers of some pigeons, which 
man has dereloped into the grotesque pouter and fantail breeds, were intended to be so developed by him, and that the variation of some dogs into the bull-dog type must have been intended to enable them to pull down bulls for man's brutal sport.

As for the latter instance, the theory of natural selection requires the Darwinian to assert that the dogs who acquired the bull-dog organisation and temper were benefited by it; and if man has made a bad use of the rariation, this only proves that any one may pervert a good thing to a bad purpose. But this does not prove that the good thing was designed for that purpose, any more than the fact that many medicines which when properly applied are valuable remedies may be used to poison people, proves that they were designed for the use of poisoners. The natural application of the argument from design to the bull-dog would be that God intended his peculiarities for the dog's good, and that man has sometimes perverted these to the bull's injury.

Again, in the case of the original variations from the normal pigeon-structure which man has ag'gravated into the deformities of the pouter and fantail, Darwin's reasoning appears to show an incorrect view of the argument from design. That argument is based upon two facts. First, that there are in the world of animals and plants an immense number of beautiful structures and arrangements. Secondly, that these serve useful purposes, purposes so vitally important that all animal and plant life depends upon them. Now hoth of these are wanting in the 
case of the pouter and fantail. That the useful purpose is wanting is recognised by Darwin, since his argument is based upon the uselessness. The beautiful structure is equally wanting in the deviation from the normal structure of the pigeon. That normal structure is itself beautiful, but the deviation is simply a deformity, an imperfect production of one part of the type. Hence the same reasoning which tends to show that the normal pigeon is the product of intelligence and intention, tends to show that a useless deviation from it is not. To quote the exceptional deviation against the argument from design would be as if we were to find a collection of ingenious machines fitted to serve a useful purpose, and among them one which from some defect in the workmanship was a failure; and were to use this case of failure to prove that the whole collection was not the result of intelligence and intention, because if the well-made machines were intended, the defect in the badly made one must have been intended also.

I have thought it worth while to examine these two arguments of Darwin, because not only do we find these published in his book on Animals and Plants under Domestication, but in a private letter respecting his views on religion (see vol. il of his 'Life and Letter's') he refers his correspondent to that passage, and adds that he has never seen these objections answered. He must therefore have thought them very strong, and anything written by Darwin deserves consideration; but I think this examination furnishes some evidence of the wisclom of the 
opinion which he more than once expressed to correspondents, that he had not given that long continuous study to the theistic side of his subject which would qualify him to he an authority upon it. 


\section{CHAPTER XII.}

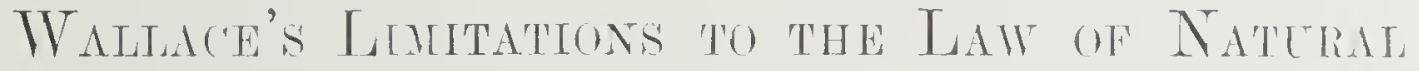 SELEC'TION.}

As Wallace was the discoverer of the theory of natural selection independently of Darwin, haring thought it out when travelling in tropical regions while Darwin was doing the same at home, we may suppose that he would not spoil the completeness and importance of that theory by denying its adequacy to account for the whole process of erolution without haring studied the subject thoroughly and finding the evidence of facts too strong to be resisted. He wrote a book called 'Natural Selection,' in which his argument in support of that, doctrine is carried through 300 pages; but he found himself compelled to acknowledge in a final chapter', entitled "The Limits of Natural Selection as applied to Man," that the theory will not account for" certain facts in the evolution of man, and that for explaining these we must fall back on the supposition of a higher intelligence or some mnknown higher laws. In fact, he arrived at the same general conclusion which it is the purpose of the present book to establish, that although natural selection can do 
much it cannot do everything, and that where it falls short we must resort to the intervention of a Being possessing intelligence, intention, and power. He, howerer, suggests an alternative theory, that of an unknown higher law, which is entirely his own; and as the facts and arguments which have led him to this result are entirely distinct from those which have been presented in the preceding chapters, their whole weight has to be added to whaterer value may be attached to the latter. The reader is strongly recommended to study Wallace's book, but in the meantime a summary is offered here.

His first and principal argument is founded on the variation in the dimensions of hmman skulls from the earliest ages to the present time. He first points out that the brain of the higher anthropoid apes, the ourang and the gorilla, varies from twentyeight to thirty cubic inches, and in one case reached thirty-four cubic inches. He then states that the collections of Dr. J. B. Davis and Dr. Morton give the following as the arerage internal capacity of the cranium among the chief races of mankind-. Teutonic 9\& cubic inches, Esquimaux 91 cubic inches, Negro 85 cubic inches, Australians and Tasmanians 82 cubic inches, Bushmen 77 cubic inches. He then informs us that the few remains of prehistoric man do not indicate any material inferiority in the size of the brain. A Swiss skull of the Stone Age corresponded exactly to that of a Swiss youth of the present time. The Neanderthal skull is estimated to have had 75 cubic inches. "The Engis skull, perhaps," he adds, "the oldest 
known, and which, according to Sir John Lubbock, 'there seems no doubt was really contemporary with the mammoth and the cave bear', is yet, according to Professor Huxley, 'a fair average skull, which might have belonged to a philosopher or might have contained the thoughtless brains of a savage.' Of the care men of Les Eyzies, who were undoubtedly contemporary with the reindeer in the sonth of France, Professor Paul Broca says (in a paper read before the Congress of Prehistoric Archæology in 1868) - 'The g'reat capacity of the brain, the development of the frontal region, the fine elliptical form of the anterior part of the profile of the skull, are incontestable characteristics of superiority, such as we are accustomed to meet with in civilised races;' yet the great breadth of the face, the enormons development of the ascending ramus of the lower jaw, the extent and roughness of the surfaces for the attachment of the muscles, especially of the masticators, and the extraordinary development of the ridge of the femur indicate enormous muscular power and the habits of a savage and brutal race."

These figures and descriptions are considered by Wallace to show that the skull of the race to which the Engis skull and those of the men of the Eyzies Cave belonged were not greatly inferior to those of civilised races, while yet Broca's description of the anatomy of the men, and all the remains which the prehistoric men have left, indicate a very low condition of savagedom. He infers that a much less capacious skull would have been sufficient for this 
condition. He argues that if the law of the survival of the fittest tends to improve a savage race up to the conformation most useful for the requirements of sarage life, it has no tendency to carry the improvement any further. And he concludes that the higher development of these skulls must have been produced in preparation for the higher civilisation which mankind were destined to attain.

Another consideration is suggested by the measurements cited by Wallace. The Darwinian theory teaches that monkeys and men are descended from a brute ancestor, who possessed the structures common to both kinds. Now we must suppose that the cranial capacity of this animal dic not exceed that of the present monkeys, twenty-eight or thirty cubic inches, or in an exceptional case thirty-four. This would, therefore, be the capacity of the skull of the first animal of the series which was to end in man. By the time of the owner of the Engis skull and that of the Cave men of Les Eyzies this capacity had risen to an amount which cannot be exactly defined, but which can hardly have been less than that of the Neanderthal skull, serenty-seven cubic inches. But let us say only seventy cubic inches; that is more than double that of the Simian ancestor. Now if we consider the nature of natural selection as defined by Darrin, that process must have been put to a hard strain before this doubling was completed. For the acciclental occurrence of a variation tending to an improvement must have been a lare event, and the amount of the rariation must have been small, as was insisted on by Darwin. When 
such did occur, its perpetuation was far from secure, and might be prevented by any one of the accidents incident to sarage life. The rate of improvement must therefore have been extremely slow, and the duplication must have occupied a very long time for its completion. It is true that the Darrinian has unlimited past time behind him-at least as far as the time occupied by the deposit of the Tertiary strata will allow. But the production of such an immense change in one organ implies such a persistent activity of favourable acciclents, that one would like to know if any similar case can be found.

Wallace also finds facts for which natural selection cannot account in the absence of hair from the back of man alone among mammals, in the ar'angement of the hair on the arms, and in the peculiar perfection of the human roice. The argument from the absence of hair on the back appears peculiarly strong. The Simian ancestor must have had hair on that part, both because this is the case with all the other mammalia, and because his descendants, the monkeys, have it. Now, according to the Darrinian theor's, his other descendants, our semi-human or human ancestor's, must have got rid of it from that part because it was a disadvantage to them. But instead of this the loss must have been a disadvantage as long as they remained without clothing. This is shown by the conduct of the inhabitants of Tierra del Fuego, who, when they have a skin or other kind of protection, apply it to their backs as the place most sensitive to cold. 


\title{
CHAPTER XIII.
}

\author{
CONCLUSION.
}

In the riews put forward in the preceding pages are correct, the phenomena presented by the first appearance of living things on the earth, and by all the changes which have resulted in producing the present condition of the animal creation and of man, cannot be completely accounted for by natural selection, but have required the intervention of intelligence commanding the power of carrying its intentions into effect. Even if a large part of these arguments is rejected, the part which will remain will be sufficient to support the same conclusion. I should be disposed to go a step farther, and if the whole of the preceding chapters except that on electric fishes were rejected, I would ask the reader to suspend his judgment until a Darwinian shall arise who will solve the question which Darwin found insoluble, of the process by which the various species of these fishes became possessed of a complete electric battery occupying a considerable portion of their inside. This does not exclude the action of Natural Selection. On the contrary, it acknowledges that this principle has played a very 
important part in evolution. It only asserts that there have been stages in evolution in which it would not have been adequate to the work without the interposition of a cause possessing intelligence, intention, and the power to carry out its intentions. The earliest of these stages was the first appearance of living things on the earth. Perhaps the last was when the Simian ancestors of man were to be endowed with that immense capacity for intellectual and moral improvement which we find in the higher races of mankind compared with monkeys, and the power of occasionally producing individuals with powers rising high above the average, to which we give the name of Genius.

The question suggests itself, Does not this imply the existence of a person possessing these qualities of intelligence, intention, and power: It certainly appears to do this, as we neither know nor can conceive intelligence and intention except as qualities of a person.

As some readers may object to the introduction into a scientific discussion of the iclea of a Divine person as a cause of phenomena, I will conclude with a passage recently reported in the 'T'imes' from a speech by Lord Kelvin, whose authority on scientific subjects no one will dispute. 
"Jord Kentin on Reulilon anu Schence.

"In connexion with University College Christian Association the first of a course of five public lectures on 'Christian Apologetics' was delivered last evening in the Botanical Theatre, at University ('ollege, Gower Street. Lord Reay, President of University College, occupied the chair, and the large theatre was filled to orerflowing, many visitors being unble to find seats.

"The Rev. Professor G. Henslow, who was the lecturer, spoke on the subject of "Present Day Rationalism : an Examination of Darwinism.'

"Lord Kelvin, in moring a vote of thanks to the lecturer, said he wished to make a personal explanation. He had recently had occasion to make use of the expressions ether, atoms, electricity, and had been horrified to read in the Press that he had spoken of ether-atoms. Ether was absolutely nonatomic; it was absolutely structureless and homogeneous. He was in thorough sympathy with Professor Henslow in the fundamentals of his lecture, but he could not say that with regard to the origin of life science neither affirmed nor denied creative power. Science positively affirmed creative power. ścience made every one feel a miracle in himself. It was not in dead matter that they lived and moved and had their being, but in the creating and directive power which science compelled them to accept as an article of belief. They could not escape from that when they studied the physics and dynamics of 
living and dead matter all around. Modern biologists were coming once more to a firm acceptance of something, and that was a vital principle. They had an unknown object put before them in science. In thinking of that object they were all agnostics. They only knew God in His works, but they were absolutely forced by science to admit and to believe with absolute confidence in a directive power-in an influence other than physical, dynamical, electrical forces. Cicero had denied that they could have come into existence by a fortuitous concourse of atoms. There was nothing between absolute scientific belief in creative power and the acceptance of the theory of a fortuitous concourse of atoms. Was there, he asked, anything so absurd as to believe that a number of atoms by falling together of their own accord conld make a crystal, * a sprig of moss, a microbe, a living animal? People thought that, given millions of years, these might come to pass, but they could not think that a million of millions of millions of years could give them unaided a beautiful world like ours. They liad a spiritual influence, and in science a knowledge that there was that influence in the world around them. He admired the healthy, breezy atmosphere of free thought in Professor Henslow's lecture. Let no one, he urged, be afraid of true freedom. They conld be free in their thought, in their criticisms, and with freedom of thought they were bound to

* N.B.-Lord Kelvin, by a letter in the 'Times,' May 4th, 1903, desires that the word "crystal" shall be deleted, leaving his argument to depend on the phenomena of organic matter. 
come to the conclusion that science was not antagonistic to religion, but a help for religion." 'Times,' May 2nd, 1903.

If it is objected that we have no direct knowledge that such a Being exists, and that without such knowledge we have no right to assume His existence and action in order to explain phenomena; it may be answered that the reality of the Ether of the Undulatory Theory of Light is believed on no other ground, and has yet been universally accepted for many year's as a scientific truth. No one professes to have seen the Ether-we have no knowledge of its existence except from the effect which we ascribe to it - and yet it is accepted as the foundation of a great theory. But it has been said that this Ether and its Undulations are not to be believed as a fact, but only to be used as a convenient working hypothesis; and it has been predicted that a time will come when it will be discarded, like Phlogiston, and consigned to the lumber-room of Science, where this Phlogiston, the Ptolemaic system of the miverse, and other dead and exploded theories are hung up, which have only an historic interest. But is it really the case that it has no more intrinsic reality than Phlogiston, which has not only failed to prove itself a truth, but has been proved to be a falsehood? In order to answer this question let us consider how a true theory is to be distinguished from a mere working hypothesis. Every one who propounds an liypothesis to account for a certain class 
of facts, frames it so as to explain and fit into these, so far as they are known at the time. In this first stage it is difficult to distinguish between the two things, but when the progress of knowledge has revealed a multitude of new facts which the theory ought to explain if it is a true theory founded on a truth of nature, it will fit into the new facts as well as into the old; while if it is only a working hypothesis formed in the inventor's mind, but having no counterpart in nature, it will sooner or later come into collision with an awkward fact which will upset it. This is the history of the Geocentric Theory which Hipparchus worked out with his mechanism of cycles and epicycles, so as to fit into the astronomical facts known to him, or at least not to come into violent collision with any, but which became ummanageable when it had to be applied to the immense distances among the heavenly bodies which have become known to astronomers since his time. As for Phlogiston, it would be a very superfluous labour to show its inability to deal with the new chemistry.

But as for the Ether and its Undulations, let us test its reality by bringing it into contact with two moder'n discoveries respecting light, of which certainly neither Huyghens, the propounter of the Undulatory 'Theory, nor' Young, the reviver' of it, had any idea. The first is the discovery of the Fraunhofer dark lines. When the doctrine of the Undulations was applicd to explain these lines, it was found to fit into them as well as if Huyghens had had them in riew while framing his hypothesis. 
Sixty or seventy years ago F'orbes (James David), then Professor of Natural Philosophy in the University of Edinburgh, was showing the Fraunhofer lines to some students; he told them that he could not explain them, that he had no idea what they meant, but he preclicted that when the real cause of them was discovered it would throw a great light on the real nature of light. His sagacity divined that a phenomenon so singular would only be explained by the application of the true cause. It was a lock which only the right key would open. Since that time, about 1850, an explanation founded on the Undulatory Theory was applied, and found to be the right key.

The second case is exhibited in such a book as Miss Agnes M. Clerke's 'Problems of Astrophysics.' The reader will there see that the power of modern telescopes having brought within the reach of our observation and exannimation the star's which Huyghens could only view as luminous points, we can know what each is mate of, and a great deal of information about the conditions of each star. But he will also learn that all this has only been acquired by taking for granted the reality of the Ether and of the Undulations, and through the Fraunhofer lines.

These two cases have been selected to illustrate what has been said on the distinction between a true theory and a mere working hypothesis, destined to be thrown away as soon as it ceases to be useful, because the statement of them does not call for much technical knowledge either in the writer or the rearler. Probibly, if an expert were to give 
his attention to the subject, he would find many other cases illustrating equally well the same principle. On the other hand, I am not aware that the Undulatory Theory has encountered any phenomenon incompatible with it. In the meantime it is hoped that these two cases will suffice to show that the Ether has done something to show it has a real existence.

The argument of this book tends to show the intervention of a Being possessing the attributes of intelligence, intention, and power. If so much is admitted we may add a fourth attribute, Eternity. For otherwise we must suppose a time when He was non-existent, and then we must suppose Him to have come into existence without any conceivable cause. The Biological argument goes no fartherand all beyond this is the province of the Theologian.

FRINTED EF ADLARD AND SON, TONDON AND DORKING. 






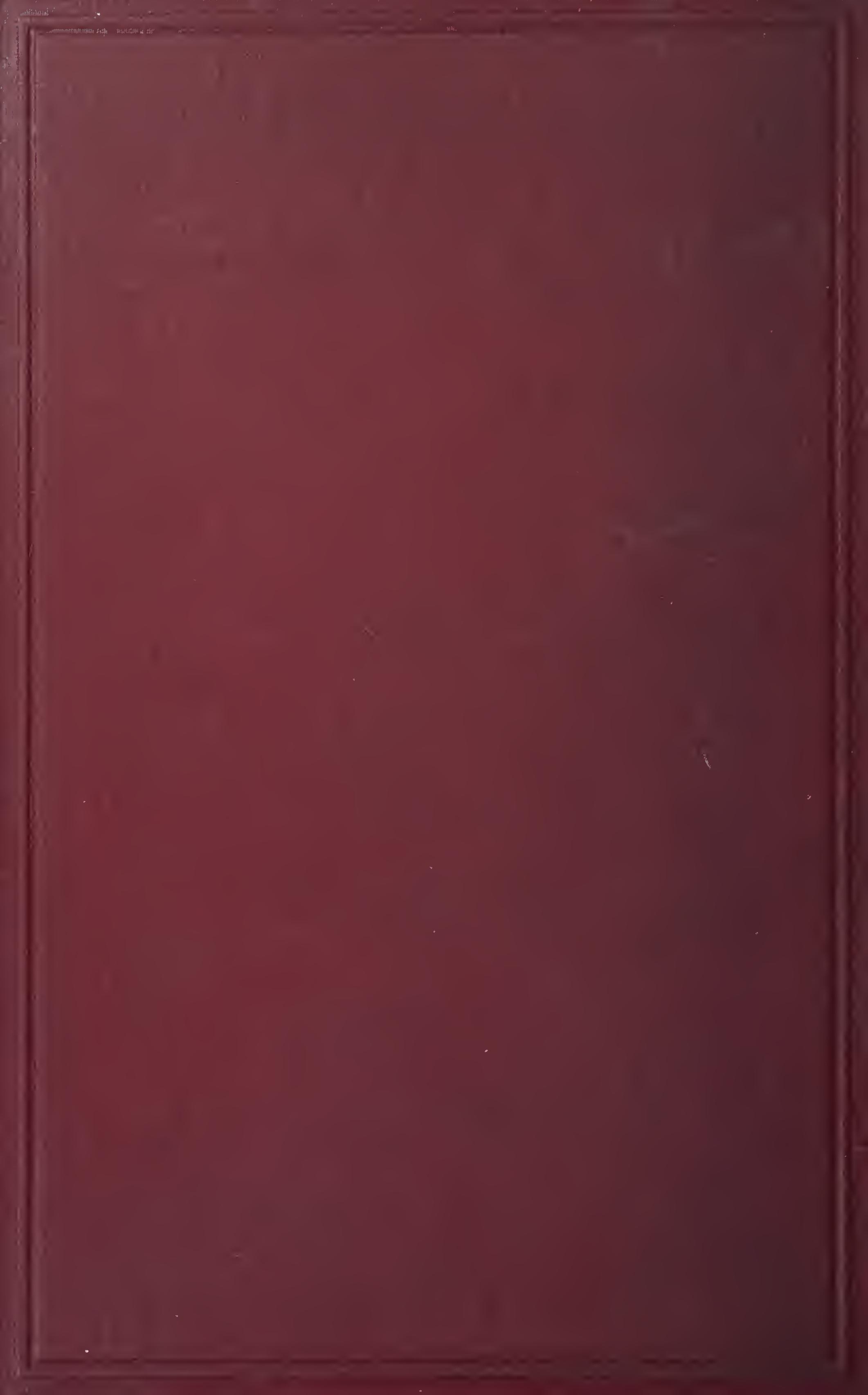

